\title{
RETHINKING THE DISCLOSURE PARADIGM IN A WORLD OF COMPLEXITY $^{\dagger}$
}

Steven L. Schwarcz*

In a prior article, Professor Schwarcz examined the factors that differentiate Enron's questionable use of off-balance sheet special purpose entities, (SPES) from the trillions of dollars of "legitimate" securitization and other structured-finance transactions that use SPEs. The presence of meaningful differences, Professor Schwarcz argued, may inform regulatory schemes by providing a basis to distinguish which such transactions should be allowed or restricted. In that connection, Professor Schwarcz encountered the dilemma that some structured transactions are so complex that disclosure to investors of the company originating the transaction is necessarily imperfect-either oversimplifying the transaction, or providing detail and sophistication beyond the level of even most institutional investors and securities analysts. In this article, Professor Schwarcz focuses on solutions to this dilemma, arguing that complexity forces a rethinking of the long-held disclosure paradigm of securities law.

"[T]he difficulty of distinguishing good quality from bad is inherent in the business world."

$\dagger$ Copyright $\odot 2004$ by Steven L. Schwarcz.

* Professor of Law, Duke University School of Law; Adj. Professor of Business Administration, Fuqua School of Business; Founding Director, Duke Global Capital Markets Center. E-mail: schwarcz@law.duke.edu.

The author thanks William M. Bratton, Brian Cheffins, Thomas Lee Hazen, Kimberly D. Krawiec, Donald Langevoort, Ralf Michaels, Frank Partnoy, Daniel B. Schwarcz, Paul M. Shupack, and Todd J. Zywicki, and participants in an "Enron Day" faculty symposium at Harvard Law School, a John M. Olin Program in Law and Economics Workshop at The University of Chicago Law School, and other faculty workshops at Duke Law School, University of Illinois College of Law, University of North Carolina-Chapel Hill School of Law, and William and Mary School of Law, for invaluable comments; and Emily A. Locher, W. Christopher Rabil, Paul M. Schoenhard, and Matias Avila Nores for excellent research assistance.

1. George A. Akerlof, The Market for "Lemons": Quality Uncertainty and the Market Mechanism, 84 Q.J. ECON. 488, 500 (1970). 


\section{INTRODUCTION}

Though itself sui generis, ${ }^{2}$ the Enron debacle highlights the increasingly widespread problem of complexity, ${ }^{3}$ illuminating concerns that arise in-and indeed are intrinsic to-virtually all securitization and derivatives deals and other forms of structured-financing transactions (structured transactions) ${ }^{4}$ In Enron's case, the company engaged in a range of manipulative accounting transactions that contributed to its downfall. ${ }^{5}$ Its primary motivation was to minimize financial-statement losses and volatility, ${ }^{6}$ accelerate profits, ${ }^{7}$ and avoid adding debt to its balance sheet, which could have hurt Enron's credit rating and thereby damage its credibility in the energy trading business. ${ }^{8} \mathrm{~A}$ common factor in these manipulations was the use of nonconsolidated special purpose entities (SPEs) to hedge certain Enron investments. ${ }^{9}$

In a typical transaction, Enron would transfer its own stock, or rights therein, to an SPE in exchange for a note or cash,$^{10}$ and also would directly or indirectly guarantee the SPE's value. ${ }^{11}$ The SPE, in turn, would hedge the value of a particular investment on Enron's balance sheet, using the transferred Enron stock as the principal source of payment. ${ }^{12}$ Because of its historically rising stock price, Enron apparently

2. John C. Coffee, Jr., Understanding Enron: "It's About the Gatekeepers, Stupid," 57 Bus. LAW. 1403, 1403-04 (2002) (arguing for Enron's uniqueness).

3. I use the term "complexity" in its ordinary meaning: the state of being complicated. FUNK \& WAGNALL'S STANDARD DICTIONARY 144 (2d ed. 1993).

4. Although I analyze complexity in the context of structured transactions, the problems of complexity discussed in this article are not unique to those transactions; thus, my analysis should apply in other transactional contexts where complexity may become problematic.

5. See generally Steven L. Schwarcz, Enron and the Use and Abuse of Special Purpose Entities in Corporate Structures, 70 U. CIN. L. REV. 1309 (2002) [hereinafter Schwarcz, Use and Abuse of Special Purpose Entities].

6. William C. Powers, Jr. et al., Report of Investigation by the Special Investigative Committee of the Board of Directors of Enron Corp. 4, 68, 78, 97 (2002) [hereinafter Powers Report], available at http://news.findlaw.com/hdocs/docs/enron/sicreport/sicreport020102.pdf.

7. E-mail from Jennifer Francis, Associate Professor of Accounting, The Fuqua School of Business, to Steven L. Schwarcz, Professor of Law, Duke University School of Law (Apr. 7, 2002, 12:16 EST) (on file with author).

8. Powers Report, supra note 6, at 36.

9. For an argument that Enron's downfall may have resulted partly from certain misrepresentations unrelated to SPE transactions, see Frank Partnoy, A Revisionist View of Enron and the Sudden Death of "May," 48 VILL. L. REV. 1245, 1245-46 (2003) [hereinafter Partnoy, A Revisionist View of Enron].

10. See, e.g., Powers Report, supra note 6, at 13.

11. Id. at 36-37.

12. See, e.g., id. at 13. Although not used in the original "Chewco" SPE transaction, hedging was used in virtually all subsequent SPE transactions. Id. These hedged transactions can be schematically represented as follows: 
judged the risk that it would have to pay on its guaranties as remoteand the risk that Enron would have to make such payments at the same time that the SPE-hedged investments fell in value was even more remote. But Enron's stock price and the value of its SPE-hedged investments did simultaneously fall, triggering the Enron guaranties while depriving the SPEs of sufficient assets to perform the hedges. ${ }^{13}$ This combination of events led to a swift downward spiral in Enron's financial condition. ${ }^{14}$

I argued in a prior article that there are meaningful economic differences ${ }^{15}$ between Enron's manipulations and the trillions of dollars of non-Enron structured transactions that use SPEs, ${ }^{16}$ of which securitization transactions ${ }^{17}$ constitute the bulk. ${ }^{18}$ For example, unlike in Enron,

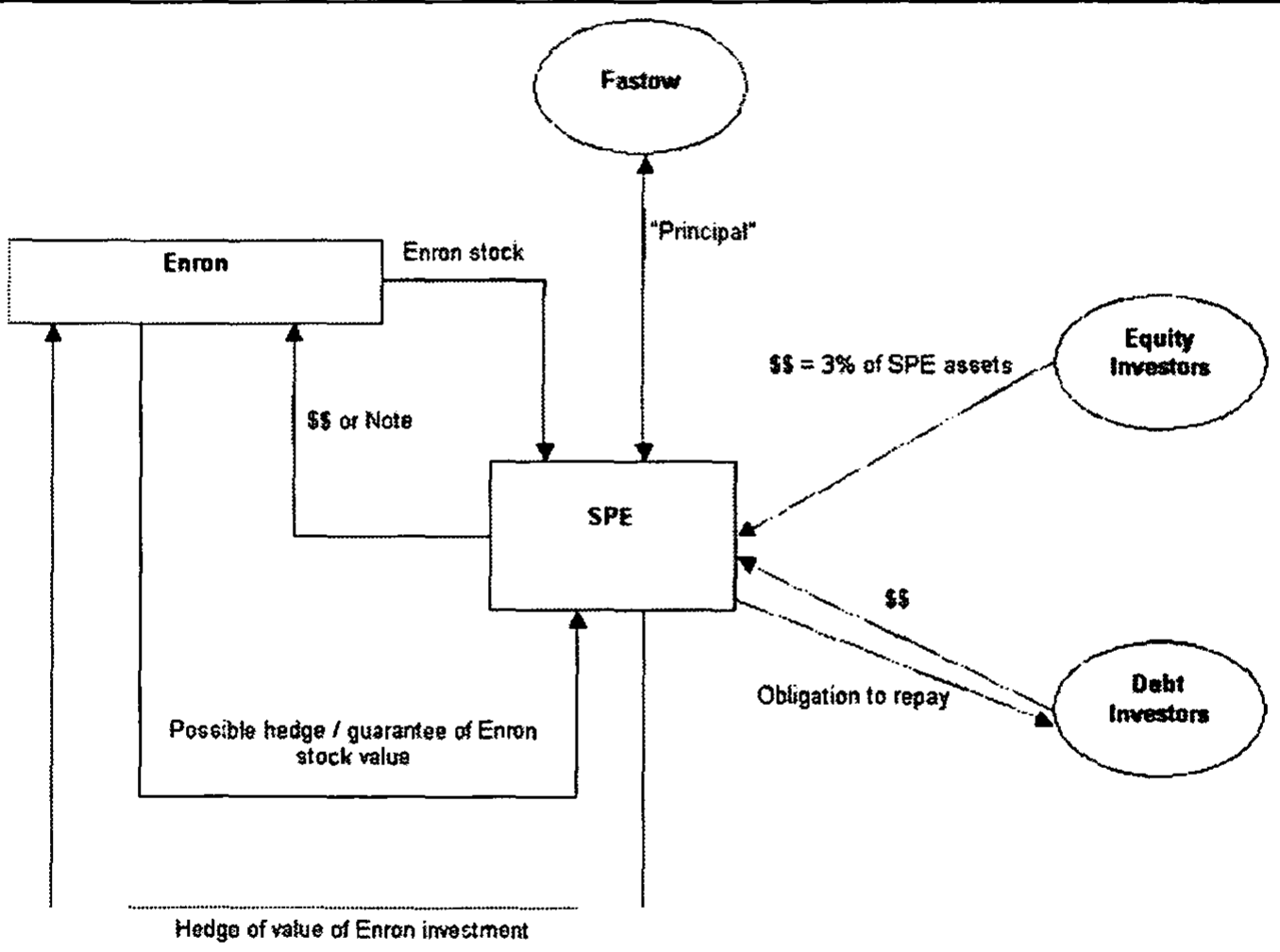

13. See Schwarcz, Use and Abuse of Special Purpose Entities, supra note 5, at 1310,1315-16.

14. The guarantee payments apparently further reduced Enron stock value, triggering additional guarantees, while the inability of the SPEs to perform their hedge resulted in a restatement of Enron's earnings. Id. at 1310. Plus, in some cases the ab initio lack of sufficient SPE third-party equity caused the SPEs to breach the three percent independent equity requirement for non-consolidation, thereby bringing the SPEs' debt onto Enron's balance sheet. See id. at 1310-11.

15. Being economic, these differences are not discernable from the legal structure of a given transaction. If they were, this article would not be needed because government could simply ban all Enron-type transactions.

16. Schwarcz, Use and Abuse of Special Purpose Entities, supra note 5, at 1314.

17. In a typical securitization transaction, a company transfers rights to payment from incomeproducing financial assets - such as accounts receivable, loans, or lease rentals - to an SPE, which in turn transfers such rights to a second SPE, which in turn issues securities to capital market investors. The second SPE uses the proceeds of the issuance to pay the first SPE for the financial assets, and the first SPE then uses those proceeds to pay the company. The investors, who are repaid from collections 
structured transactions typically transfer substantive risk away from the company originating, or sponsoring, the transaction (the originator) ${ }^{19}$ to the SPE, thereby justifying off-balance sheet financing. ${ }^{20}$ Additionally, structured transactions are often used "to obtain lower-cost-financing through disintermediation, or removal of intermediaries such as bank lenders between the [originator] and the ultimate source of funds, the capital markets." ${ }^{21}$ Thus, these transactions are normally viewed as socially desirable..$^{22}$

Notwithstanding that desirability, these transactions are always extremely complex and, in the case of securitizations, often rely on multiple SPEs. ${ }^{23}$ Furthermore, in order to integrate disparate disciplines such as bankruptcy, tax, securities law, commercial law, accounting, and finance, structured transactions often appear to be highly convoluted. ${ }^{24}$ Disclo-

of the financial assets, buy the securities based on their assessments of the value of the financial assets. See Steven L. Schwarcz, The Inherent Irrationality of Judgment Proofing, 52 STAN. L. REV. 1, 6 (1999) [hereinafter Schwarcz, The Inherent Irrationality of Judgment Proofing]. For a more complete analysis of securitization, see STEVEN L. SCHWARCZ, STRUCTURED FINANCE: A GUIDE TO THE PRINCIPLES OF ASSET SECURITIZATION (Adam D. Ford ed., 3d ed. 2003) [hereinafter STRUCTURED FinANCE]; Steven L. Schwarcz, The Alchemy of Asset Securitization, 1 STAN. J.L. BUS. \& FIN. 133 (1994) [hereinafter Schwarcz, The Alchemy of Asset Securitization].

18. See, e.g., Diana B. Henriques, The Brick Stood up Before. But Now?, N.Y. TIMES, Mar. 10, $2002, \S 3$, at 1 (referring to SPEs used in securitization transactions as "the most common specialpurpose entities"); see also STRUCTURED FINANCE, supra note 17, $\S 1$ : at 1-2 (discussing the relationship between structured finance and securitization).

19. I use the term "originator" to help distinguish companies that originate transactions from SPEs created to help effectuate transactions.

20. Schwarcz, Use and Abuse of Special Purpose Entities, supra note 5, at 1315; see also infra notes 126-31 and accompanying text (discussing transfer of investment risk).

21. Schwarcz, Use and Abuse of Special Purpose Entities, supra note 5, at 1315.

22. See, e.g., Claire A. Hill, Securitization: A Low-Cost Sweetener for Lemons, 74 WASH. U. L.Q. 1061, 1085-111 (1996) [hereinafter Hill, Securitization: A Low-Cost Sweetener for Lemons]; see also infra notes 124-31 and accompanying text (explaining the benefits of structured transactions). But cf. Lynn M. LoPucki, The Death of Liability, 106 YALE L.J. 1, 24-25 (1996) (arguing that structured transactions can lead to judgment proofing). I counter Professor LoPucki's arguments in Schwarcz, The Inherent Irrationality of Judgment Proofing, supra note 17.

23. See Hill, Securitization: A Low-Cost Sweetener for Lemons, supra note 22, at 1063; see also Schwarcz, Use and Abuse of Special Purpose Entities, supra note 5.

24. This can be illustrated by the following simplified schematic of a healthcare securitization conduit established by a leading investment firm, with the author's counsel, in order to provide lowcost financing to hospitals. Its purposes were salutary on all levels, but its structure might appear unnecessarily complex: 
sure of a complex and convoluted structure to investors of the originator-the audience on which this article primarily focuses-may well be either too detailed for many of those investors, even institutional investors, to understand and assimilate,$^{25}$ or too superficial to allow investors to fully assess the transaction and its ramifications. ${ }^{26}$ The problem is compounded where, as is common, an originator engages in numerous such transactions. ${ }^{27}$

In Enron, for example,$^{28}$ there is no dispute that the existence of the SPE-transactions was generally disclosed to Enron's investors. ${ }^{29}$ The dis-

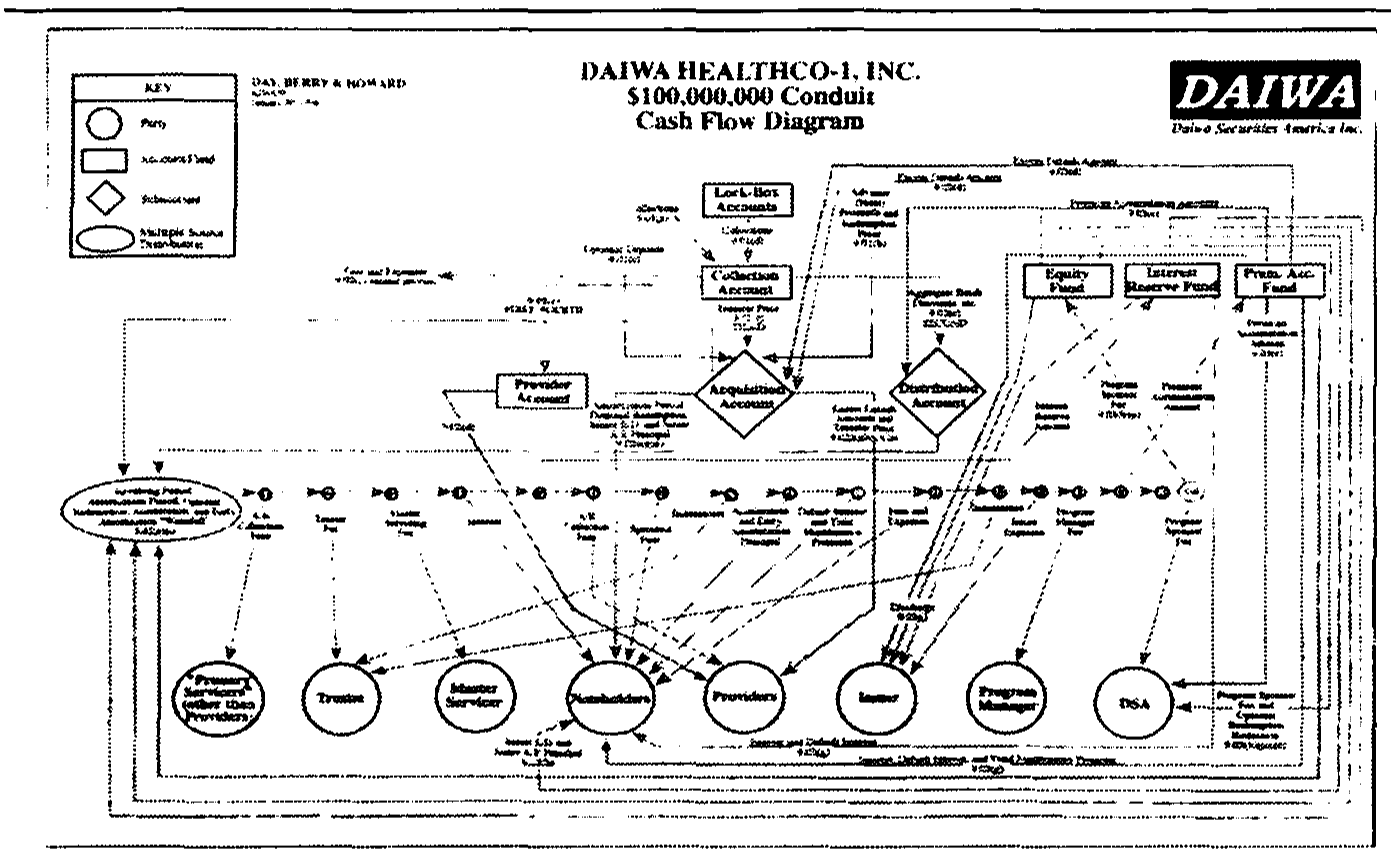

25. See infra notes $75-82$ and accompanying text.

26. A possible response is to require both levels of disclosure: a simple but potentially insufficient level intended for all of the originator's investors, and the fully extensive level given to the SPE's investors. The latter information, for example, could be required to be placed on file with the SEC and available for interested parties. This response, however, would significantly raise the cost of disclosure, while not necessarily helping investors who cannot understand the higher level of disclosure. Also, it would not work where, as is common, the detailed structure of the transactions are confidential-such as for private placements where the deal structure is viewed as a trade secret not intended for public dissemination. See, e.g., Bank of Am., N.A. v. Patriarch Partners, LLC, No. 3:01-CV-547MU, (W.D.N.C. filed Sept. 24, 2001) (lawsuit claiming improper use of trade secret consisting of details of securitization transaction); see also E-mail from Frank Partnoy, Professor of Law, University of San Diego School of Law, to Steven L. Schwarcz, Professor of Law, Duke University School of Law (Sept. 17, 2002, 21:38 EST) (on file with the author) (observing that his former colleagues at the Morgan Stanley investment-banking firm "would have balked at the idea" of permitting disclosure of the details of deals).

27. See Schwarcz, Use and Abuse of Special Purpose Entities, supra note 5.

28. Although the SPE transactions in Enron are not generally illustrative of structured transactions, all of these transactions share the characteristic of complexity.

29. See Powers Report, supra note 6, at 200-01 ("[W]hile it has been widely reported that the related-party transactions connected to Fastow involved 'secret' partnerships and other SPEs, we believe that is not generally the case.... [T]he fact remains that the LJM partnerships, the Raptor entities, and transactions between Enron and those entities all were disclosed to some extent in Enron's public filings."). 
closure itself, however, was ultimately said to be inadequate. ${ }^{30}$ Although this inadequacy might have been intentionally fraudulent, the better explanation is that Enron's structured transactions were so complex that disclosure either would have had to oversimplify the transactions or else provide detail and sophistication beyond the level of both ordinary and otherwise savvy institutional investors in Enron securities. ${ }^{31}$ The same explanation accounts for the failure of many institutional investors and securities analysts to understand non-Enron structured transactions. ${ }^{32}$ This explanation, however, goes to the very heart of securities regulation, which relies exclusively on disclosure as its regulatory methodology, ${ }^{33}$ and on sophisticated investors and analysts to bring market prices into line with disclosure. ${ }^{34}$

This article questions whether securities regulation should continue to rely exclusively on disclosure. Part II.A of the article argues that, in a world of complexity, disclosure can be insufficient to remedy the information asymmetry ${ }^{35}$ between the originator and its investors. ${ }^{36}$ Part II.B of the article examines possible responses to this information insufficiency: to tolerate it; to ban or proscribe transactions for which the information asymmetry exceeds certain bounds; or to require supplemental

30. See id. at 197 (contending that, notwithstanding disclosures of the existence of the SPEs to Enron's investors, such disclosures "failed to achieve a fundamental objective: they did not communicate the essence of the transactions in a sufficiently clear fashion to enable a reader of [Enron's] financial statements to understand what was going on"); see also id. at 17, 192.

31. Schwarcz, Use and Abuse of Special Purpose Entities, supra note 5, at 1316-17; cf. Graydon "Dee" Hubbard, Early Signs of Failure Evident in Enron Collapse, Hous. Bus. J., Apr. 5, 2002 (arguing that although "analysts, investment bankers, investors and lenders had enough information [from Enron's audited financial statements] to see" Enron's demise, they failed to do so), available at http:/www.houston.bizjournals.com/houston/stories/2002/04/08/editorial3.html.

32. See infra notes $79-82$ and accompanying text (arguing that complexity goes far beyond Enron, that relatively few people can understand structured transactions, and that some transactions may not even be understandable by any single person).

33. See infra note 72 and accompanying text.

34. See infra notes $43-44$ and accompanying text (discussing how scholars initially envisioned sophisticated market intermediaries would filter information to investors), notes 102-03 and accompanying text (discussing the efficient market hypothesis, under which scholars and regulators presently see market prices reflecting disclosure).

35. A related question is whether some structured transactions are, or can be, so complex that, rather than an information asymmetry, there is an inherent lack of information on both sides - the originator's management and the investors. It appears that few of Enron's board members understood its SPE transactions. Powers Report, supra note 6, at 23 (observing that although Enron's board authorized the Rhythms transaction and three of the Raptor transactions, "it appears that many of its members did not understand those transactions - the economic rationale, the consequences, and the risks"). There is a similar lack of understanding in derivatives transactions. See, e.g., Margery Waxman, The Lesson of Orange County: It Takes a Crisis to Focus Public Policy on the Need for Adequate Disclosure of Risk, 63 Banking Rep. (BNA) No. 23, at 944 (Dec. 19, 1994) ("There is no doubt that the complexity of [derivatives] transactions has made it more difficult for even the most sophisticated senior management to understand or evaluate the benefits or the risks associated with using these derivatives."). Although beyond the scope of this article, the consequences of this lack of information and the normative response thereto may be matters worthy of further research.

36. Those investors are, of course, the originator's shareholders and bondholders-i.e., its equity and debt investors. They should be distinguished from the very narrow and highly specialized class of sophisticated investors in securities issued by the SPEs that are parties to the originator's structured transactions. 
protections to minimize that asymmetry or mitigate its consequences. ${ }^{37}$ Part II.B.1 shows that the long-standing belief that markets will compensate for disclosure's insufficiency-the efficient market hypothesis-is not justified in a world of complexity, and that relying on investors to discount the share price of originators engaging in complex transactions would be inefficient. ${ }^{38}$ Thus, toleration of disclosure's insufficiencies is undesirable. Part II.B.2 contends that the second response, proscribing complex transactions, would be socially harmful. ${ }^{39}$ Part II.B.3 argues for the third response, maintaining that disclosure should be supplemented by cost-effective protections, particularly in the area of corporate governance. ${ }^{40}$ Absent adequate disclosure, an originator's investors may have to rely on the business judgment of the originator's management in entering into a complex transaction for the originator's benefit. This reliance can be protected by requiring management-in transactions in which complexity renders any form of disclosure insufficient - to be free of material conflicts of interest stemming from those transactions. This would minimize the opportunity for fraud and enhance investor confidence by prohibiting the most troublesome conflicts of interest that tempt managers to engage in fraudulently complex transactions. ${ }^{41}$

\section{ANALYSIS}

Analysis of the tension between investor understanding and complexity remains scant. During the debate over the original enactment of the federal securities laws, Congress did not focus on the ability of investors to understand disclosure of complex transactions. ${ }^{42}$ Although schol-

37. See discussion infra Part II.B.1-.3.

38. See infra Part II.B.1.

39. See infra Part II.B.2.

40. See infra Part II.B.3.

41. The distinction between fraudulent and nonfraudulent complexity might be likened to the distinction between three-card Monte and quantum mechanics. In the former case, the complexity is intended for obfuscation, whereas in the latter it is inherent in the nature of things.

42. Robert L. Knauss, A Reappraisal of the Role of Disclosure, 62 MiCH. L. REV. 607, 615 (1964) ("Whether the disclosure approach alone would in fact protect small investors from fraudulent schemes or the making of poor investments was generally not discussed."). The focus of the congressional debate was on whether to choose disclosure or substantive regulation of the right of companies to issue securities as the policy that would inform the securities laws. President Roosevelt, influenced by the views of Louis D. Brandeis, advocated the disclosure approach. See LouIS D. BRANDEIS, OTHER PEOPLE'S MONEY AND HOW THE BANKERS USE IT 18, 99-102 (8th prtg. 1932) (arguing that disclosure can reform the system through which bankers "control the people through the people's own money" because, by disclosing their profits to investors, bankers would be effectively forced to charge more reasonable fees). Subsequently, however, Congress did attempt to deal with complexity in the investment trusts arena by enacting the Investment Company Act of 1940, Pub. L. No. 76-768, 54 Stat. 789 (1940) [hereinafter the ' $40 \mathrm{Act}$ ], which imposes both disclosure requirements and substantive regulations. See 86 CONG. REC. 2844 (1940) (statement of Sen. Wagner) ("The underlying purpose of the legislation is not merely to ensure to investors a full and fair disclosure . . but to eliminate and prevent those deficiencies and abuses in these organizations which have contributed to the tremendous losses sustained by their security holders."); 86 CONG. REC. app. at 1478 (1940) (editorial from the New York Times on Mar. 16, 1940) ("It does not require the simplification of existing systems of investment companies, but does try to eliminate the evils of complex capital structures in the future."). 
ars assumed that ordinary investors would not have that ability, ${ }^{43}$ they anticipated that sophisticated market intermediaries-such as brokers, bankers, investment advisers, publishers of investment advisory literature, and even lawyers - would help filter the information down to investors. $^{44}$

In recent years, the U.S. Securities and Exchange Commission (SEC) touched on this issue by promoting the use of plain English in an attempt to manage the growing complexity of disclosure documents. ${ }^{45}$ But plain English primarily addresses the problem of overly legalistic writing; it is not an adequate solution for the problem of inherently complex transactions. ${ }^{46}$

Complexity has also been addressed to some extent in a derivatives context. ${ }^{47}$ Because even sophisticated institutional investors can lack the ability to understand derivatives transactions, ${ }^{48}$ investments in derivative instruments have sometimes given rise to spectacular losses. ${ }^{49}$ In response, in 1997, the SEC attempted to deal with derivatives risk through disclosure. $^{50}$ Although derivatives themselves are not necessarily re-

In particular, the ' 40 Act targeted the negative behavior of interested parties as a pervasive threat to investors, and sought to minimize conflicts. See 86 CONG. REC. at $2844-45$ (statement of Sen. Wagner) ("Because of [the] absence of safeguards, promoters and managers of investment companies have been able to determine every aspect of their affairs in an atmosphere of self-dealing and conflicting interests devoid of arms-length bargaining.... In general, the theory of the [ $40 \mathrm{Act}$ ] is to eliminate wherever possible such abuses by direct prohibition of their continuance."). I later argue that complexity sometimes requires not only the usual disclosure requirements, but also substantive regulation to minimize conflicts. See infra notes 181-219 and accompanying text.

43. Disclosure to INVESTORS: A ReAPPRAISAl OF FEDERAL AdMINISTRATIVE POLICIES UNDER THE '33 AND '34 ACTS (THE WHEAT REPORT) 52 (1969) [hereinafter THE WHEAT REPORT]; accord William O. Douglas, Protecting the Investor, 23 YALE REV. 521, 524 (1934).

44. THE WHEAT REPORT, supra note 43, at 52.

45. J. Robert Brown, JR., The Regulation of CoRporate Disclosure $\$ 2.02$ [6], at 2-41 (3d ed. Supp. $2002 \&$ 2002-2).

46. Id.

47. The term "derivative" refers generically to any instrument created by a contract whose value is based on another asset or financial instrument. See generally Kimberly D. Krawiec, More than Just "New Financial Bingo": A Risk-Based Approach to Understanding Derivatives, 23 J. CORP. L. 1, 6-14 (1997).

48. See Norman S. Poser, Liability of Broker-Dealers for Unsuitable Recommendations to Institutional Investors, 2001 BYU L. REV. 1493, 1521; accord Christine Cuccia, Information Asymmetry and OTC Transactions: Understanding the Need to Regulate Derivatives, 22 DEL. J. CORP. L. 197, 206 (1997) (stating that some of the nation's most sophisticated asset managers do not understand derivatives); Partnoy, A Revisionist View of Enron, supra note 9, at 1263 n.81 (noting "skepticism that even sophisticated securities analysts could draw anything of value out of financial disclosures about derivatives") (internal citation omitted).

49. See, e.g., 1 ThOMAS LeE HAZEN, The LAw of Securities Regulation § 1.7[5], at 119 (4th ed. 2002) (referring to "Orange County California's tremendous losses [and resulting bankruptcy] as a result of" poorly understood investments in exotic derivatives); Christian O. Nagler, Note, Derivatives Disclosure Requirements: Here We Go Again, 6 CORNELl J.L. \& PUB. POL'Y 441 (1997) (providing lengthy treatment of derivatives investment failure by Bankers Trust, affecting Procter \& Gamble and Gibson Greetings); $c f$. Saul Hansell, A U.S. Look for Lessons in Barings, N.Y. TIMES, Mar. 6, 1995, at D1 (discussing downfall of Barings PLC due to a one billion dollar loss caused by derivatives trading).

50. See Martin H. Dozier, Note, Baring's Ghost: Item 305 in SEC Regulation S-K and "Market Risk" Disclosure of Financial Derivatives, 34 GA. L. REv. 1417, 1420-21 (2000). 
garded (and thus not regulated) as securities, ${ }^{51}$ the SEC issued Item 305 of SEC Regulation S-K, ${ }^{52}$ requiring companies making SEC filings to disclose their risk exposure to derivatives instruments. ${ }^{53}$ This disclosure is "intended to clarify the registrant's exposures to market risk associated with activities in derivative [and other financial] instruments." 54 The disclosure should be presented outside of the financial statements, and may even be made as part of the management discussion and analysis of financial condition and results of operations (MD\&A) portion of SEC reporting. ${ }^{55}$ The goal is to require companies to provide both quantitative ${ }^{56}$ and, to the extent material, qualitative information about derivatives risk. ${ }^{57}$

To date, there do not appear to be empirical data indicating the success or failure of derivatives disclosure. The costs imposed on companies to prepare these disclosures, however, have averaged almost $\$ 50,000,58$ substantially greater than the $\$ 8,000$ originally estimated by the SEC..$^{59}$

51. 1 HAZEN, supra note $49, \S 1.7[5]$, at 119 (discussing that, for the most part, "exotic derivatives are not subject to regulation as securities because they involve contracts between the creator and the investor where the gains of one are the losses of the other; thus, swaps and the like do not involve a common enterprise").

52. 17 C.F.R. § 229.305 (2003). Regulation S-K "contains the informational disclosure requirements for both the 1933 [Securities] Act and the 1934 [Securities Exchange] Act," including "a detailed description of the ways in which the disclosed information must be presented." 2 HAZEN, supra note $49, \S 9.4[2]$, at $23-24$.

53. 17 C.F.R. § 229.305; see also 1 HAZEN, supra note 49, § 1.7[5], at 120-21 (discussing Item 305 and derivatives disclosure); Quinton F. Seamons, Requirements and Pitfalls of MD\&A Disclosure, 25 SEC. REG. L. J. 239, 269-71 (1997); Dozier, supra note 50, at 1450-51. Although brokers also may be liable for their failure to adequately disclose the risks of derivatives instruments they sell, compare In re Gibson Greetings, Accounting \& Auditing Enforcement Act Release No. 730, 7 Fed. Sec. L. Rep. (CCH) II 74,245 (Oct. 11, 1995), the focus of my article is on disclosure to investors by the company purchasing such instruments. I do not focus, for example, on the question of whether derivatives markets should be regulated. Cf. The Fall of Enron: How Could It Have Happened?: Hearings Before the Senate Comm. on Governmental Affairs, 107th Cong. (2002) [hereinafter Hearings] (testimony of Frank Partnoy, Professor of Law, University of San Diego School of Law) (arguing for such regulation), available at http://www.senate.gov/ gov_affairs/012402partnoy.htm. Nor do I focus on whether the suitability doctrine should be applicable to institutional investors in derivatives. $C f$. Willa E. Gibson, Investors, Look Before You Leap: The Suitability Doctrine Is Not Suitable for OTC Derivatives Dealers, 29 LOY. U. CHI. L.J. 527, 571 (1998) (discussing whether imposing suitability obligations on derivatives dealers makes sense); Poser, supra note 48, at 1510-12 (arguing that many institutional investors lack the ability to understand the nature and risks of complex derivative-investments that securities firms sell to their customers).

54. 17 C.F.R. $\$ 229.305$ (Paragraph 1 of General Instructions to Paragraphs 305(a) and 305(b) of Item 305).

55. Id. (Paragraph 6 of General Instructions to Paragraphs 305(a) and 305(b) of Item 305). The purpose is to provide a management narrative that informs investors how the company's exposure to derivative risk is managed. See id. $\S 229.305(b)(1)$.

56. Id. § 229.305(a).

57. Id. $\$ 229.305(\mathrm{~b})$.

58. Joe Godwin, Current Accounting Projects, Remarks at 1998 Twenty-Sixth Annual National Conference on Current SEC Developments (Dec. 9, 1998) (referring to data collected by the American Bankers Association in a 1998 study), available at http://www.sec.gov/news/speech/speecharchive/ 1998/spch240.htm.

59. See Steve Burkhoder, Witnesses at Senate Hearing Split on SEC, FASB Derivatives Regulations, 29 Sec. Reg. \& L. Rep. (BNA) 322, 323 (1997). Since that time, the FASB has issued Statement 133 (SFAS 133, issued June 1998), governing accounting for investment in derivatives. Although 
More importantly, and consistent with a preimplementation survey of Item 305 conducted by the Treasury Management Association ${ }^{60}$ (in which more than half of the respondents predicted that Item 305 would not improve investor understanding of derivative exposure) there remains real concern whether derivatives disclosure is adequate. ${ }^{61}$ Professor Partnoy, for example, observes that Enron's use of derivatives was not fully transparent to Enron's investors. ${ }^{62}$ Partnoy notes that an argument can be made "that Enron satisfied its disclosure obligation" even though "the result of Enron's method of disclosure was that investors did not get a clear picture of the firm's finances." ${ }^{63}$ The SEC's former Deputy Chief of Economics argues that Item 305 requires disclosure of only market-based risks ${ }^{64}$ whereas derivatives losses " "generally involve issues unrelated to disclosure and accounting, such as poor internal controls, bad judgment, incompetence, and, perhaps, fraud." 65 Other commentators argue that Item 305-mandated disclosure of "worst case" scenarios can overemphasize unlikely risks, while ignoring risks that are more realistic. ${ }^{66}$ And, although the SEC, in response to the Sarbanes-Oxley Act of 2002, recently amended the MD\&A disclosure requirements to require an explanation of a firm's off-balance sheet arrangements and a tabular presentation of certain of its contractual obligations, that change would not even have required disclosure of the Enron transactions. ${ }^{67}$

Statement 133 requires a more simplified and uniform set of disclosures than Item 305, the SEC has not yet revised its policy in response.

60. See Suzanne McGee, Derivative Dealers Blast Rule Proposals, WALl ST. J., Sept. 26, 1996, at C16.

61. See, e.g., Peter Coy et al., Where the Risk Went, Bus. WK., Oct. 28, 2002, at 98 (observing that the "explosive growth of securitization and derivatives during the 1990s" has raised concerns about the efficacy of disclosure); see also Steve Liesman, Deciphering the Black Box: Many Accounting Practices, Not Just Enron's, Are Hard to Penetrate, WALL ST. J., Jan. 23, 2002, at C1 (quoting Philip Livingston, President of Financial Executives International, as calling the new rules for derivatives "a monstrosity of accounting standards that nobody understands," including accountants and chief financial officers).

62. Hearings, supra note 53, at 11-12 (testimony of Frank Partnoy).

63. Id. at 12; see also Partnoy, A Revisionist View of Enron, supra note 9, at 1258-59 (explaining why "Enron's disclosure arguably satisfied SEC rules").

64. Market-based risks generally result from shifts in the market of the underlying commodity, reference rate, index, asset, etc. See Krawiec, supra note 47, at 17-30 (offering a detailed analysis of market-risk assessment). Item 305 divides market risks into "interest rate risk, foreign currency exchange rate risk, commodity price risk, and other relevant market risks, such as equity price risk." 17 C.F.R. § 229.305(a)(1) (2003).

65. Burkholder, supra note 59, at 323 (quoting Kenneth Lehn, former SEC Deputy Chief of Economics); accord Krawiec, supra note 47, at 41-42 (arguing that non-market risks were at least as much to blame for the collapse of Barings, PLC).

66. See, e.g., Dozier, supra note 50, at 1477 (arguing that Item 305's requirement that companies disclose a set of the "worst case" scenarios detailing the "aggregate potential for loss" from derivatives due to hypothetical changes, see 17 C.F.R. § 229.305 (1998) (Instructions to Paragraph 305(a)), is likely to "[divert] the investor's attention from more realistic scenarios and [focus] it solely on an unlikely scenario").

67. Partnoy, A Revisionist View of Enron, supra note 9, at 1278 ("Disclosure of 'reasonably likely' contingencies would not likely have prevented the problems associated with Enron. Indeed, Enron was in compliance with the newly-enacted SEC regulations."). 
In short, in the area of complexity of structured transactions in which the SEC and commentators have devoted the most attention and scrutiny to date, disclosure does not appear to solve the asymmetric information problem. Moreover, other forms of structured transactions, such as securitizations, may raise even greater problems for disclosure than derivatives. The latter are normally arm's length transactions between unrelated parties - the company and, for example, a derivatives dealer. ${ }^{68}$ In contrast, securitization transactions often involve SPEs that are managed by one or more officers of the originator, creating the possibility - as occurred in Enron - of real conflicts of interest. ${ }^{69}$ These conflicts can undermine the reliability of disclosure. ${ }^{70}$ The existence of these conflicts makes derivatives complexity an imperfect model for analyzing complexity in structured transactions.

Furthermore, this article seeks a normative answer to the problem of complexity in structured transactions. The fact that the SEC, through Item 305 , has chosen disclosure as the positive-law means of remedying the information asymmetry in the derivatives context-even if derivatives were an appropriate model-is not necessarily compelling as a normative argument either in that context or in the context of structured transactions generally. ${ }^{71}$

This analysis therefore begins by looking to the fundamentals: the rationalization for the disclosure paradigm and whether that rationale is sufficient in cases of complexity.

\section{A. Disclosure Is Insufficient in a World of Complexity}

In the United States, "federal securities law's exclusive focus is on full disclosure." 72 The underlying rationale is that

investors are adequately protected if all relevant aspects of the securities being marketed are fully and fairly disclosed. The reason-

68. See John F. Marshall \& Kenneth R. Kapner, The Swaps Market 14-19 (2d ed. 1993) (discussing facilitators of derivatives transactions, and observing that most derivatives activity involves dealers); see also DERIVATIVEs POLICY GROUP, FrAMEWORK FOR VOLUNTARy OVERSIGHT 37 (Mar. 1995) (noting that over-the-counter "derivatives transactions are predominately arm's length transactions"); Gibson, supra note 53, at 574-77 (discussing the arm's-length nature of most over-the-counter derivatives contracts).

69. Schwarcz, Use and Abuse of Special Purpose Entities, supra note 5, at 1317-18. A contributing factor to the failure of derivatives disclosure in Enron may have been Enron's use of special purpose entities to engage in the derivatives hedging.

70. Only if these conflicts are eliminated, as I later argue should be done, would the complexity analysis of structured transactions be on a common ground, focusing on the risk that management will guess wrong and make bad investments.

71. See, e.g., Alan Schwartz, A Contract Theory Approach to Business Bankruptcy, 107 YALE L.J. 1807, 1814-15 (1998) (arguing that "the appropriate response to an 'ought' claim is an 'ought not' claim, not an 'is' claim"). I recognize, however, that Item 305 does reflect, to some extent, how regulators and others have viewed the complexity issue to date.

72. 1 HAZEN, supra note $49, \S 8.1[1][\mathrm{B}]$, at 740 ; see also id. $\$ 1.2[3]$, at 27 (explaining that "[t]he focus on disclosure was based on the conclusion that sunlight is the best disinfectant") (paraphrasing BRANDEIS, supra note 42 , at 92 ). 
ing is that full disclosure provides investors with sufficient opportunity to evaluate the merits of an investment and fend for themselves. It is a basic tenet of federal securities regulation that investors' ability to make their own evaluations of available investments obviates any need that some observers may perceive for the more costly and time-consuming governmental merit analysis of the securities being offered. ${ }^{73}$

At least one prominent commentator, Professor Ronald Gilson, has asserted that disclosure is the best way to prevent future Enron-type debacles. ${ }^{74}$ But full disclosure of structured transactions does not, as a practical matter, provide investors in the originator's securities with sufficient opportunity to evaluate the merits of an investment. Moreover, most investors do not have the ability to evaluate structured transactions.

To understand why disclosure fails in this context, consider the Enron-SPE transactions. The Powers Report, ${ }^{75}$ which attempts to describe only "the substance of the most significant [of those] transactions," over 200 pages long. ${ }^{77}$ And the Powers Report was prepared with the benefit of hindsight and with the assistance of some of the finest legal

73. 1 id. $\S 1.2[3][\mathrm{A}]$, at 28.

74. See Henriques, supra note $18, \S 3$, at 1 (quoting Professor Gilson as emphasizing disclosure: "Companies that want to use complicated structured-financing techniques should be prepared to explain them completely ... [a]nd in plain English ....").

75. See Powers Report, supra note 6.

76. Id. at 1 .

77. To the extent the complexity of Enron's SPE transactions was based more on three-card Monte than quantum mechanics, see supra note 41 and accompanying text (using this analogy to explain the distinction between fraudulent and nonfraudulent complexity), the length of the Powers Report imperfectly reflected an attempt to describe nonfraudulent SPE transactions. Based on my experience, however, I do not think its length is far off the mark for such a description. For example, a review of twenty structured-transaction disclosure documents, reflecting a cross-section of originators and SPEs, but otherwise randomly chosen, indicates that the average length of the transaction description alone in these documents is forty single-spaced print pages or, conforming to the equivalent typeface of the Powers Report, eighty-four pages. Memorandum from Emily A. Locher, J.D. 2003 Duke University School of Law \& M.B.A. 2003 Fuqua School of Business, to Steven L. Schwarcz, Professor of Law, Duke University School of Law (Mar. 3, 2003) (on file with author) (noting also that the median transaction description length was thirty-eight pages (seventy-nine pages when conformed to equivalent Powers Report typeface), and the standard deviation of the transaction description length was seventeen pages (thirty-six pages when conformed to equivalent Powers Report typeface)). Though written in plain English, these descriptions are also extremely difficult to understand, even for sophisticated readers, because of the inherent complexity of the deals they describe. E-mail from Emily A. Locher, J.D. 2003 Duke University School of Law \& M.B.A. Fuqua School of Business, to Steven L. Schwarcz, Professor of Law, Duke University School of Law (Mar. 4, 2003, 11:59 EST) (on file with author). Because a typical originator engages in multiple structured transactions (e.g., an EDGAR search for publicly filed SPE disclosure documents found, on February 27, 2003, that eight of the eighteen originators surveyed each had over fifty public deals and that five of those eight each had over 100 public deals) and there may well be, in the author's experience, additional private deals (though the originator's investors may not even be permitted to review disclosure documents prepared for private structured-transactions, particularly where, as is common, the detailed structure of the transactions are confidential; see supra note 26 and accompanying text), the job of an investor in the originator to understand all such transactions can approach the task of understanding an Enron-type situation. Although originators may try to boil down the disclosure of all these deals into a single disclosure document delivered, as applicable, to its investors, I have argued that such a level of disclosure may be too superficial to be truly meaningful. See supra note 26 and accompanying text. 
talent in the nation. ${ }^{78}$ But complexity goes far beyond Enron, involving, for example, such mainstream companies as IBM, Coca-Cola, General Electric, and American International Group. ${ }^{79}$ A recent article even claims that some structures are getting so complex that they are incomprehensible. ${ }^{80}$ To some extent, that claim is hyperbolic. If humans create the structures, then humans can decipher them. In other words, it is not that people cannot understand the structures, it is just that relatively few can do so, ${ }^{81}$ and some structures may not even be able to be understood by any single person..$^{82}$

This nonetheless begs the question whether institutional investorsor securities analysts, on whom investors often rely-will hire teams of structured-transaction experts as needed to decipher complex deals. The evidence suggests they do not, ${ }^{83}$ and theory explains why. Although ex-

78. See Press Release, Enron Corp., Enron Special Comm. Completes Investigation and Issues Report (Feb. 2, 2002), at http://www.enron.com/corp/pressroom/releases/2002/ene/020202ReleaseLtr. html (stating that the investigation was "conducted over approximately three months with the assistance of experienced legal counsel from Wilmer, Cutler, \& Pickering").

79. Liesman, supra note 61 , at $\mathrm{Cl}$ (explaining that "corporations, and what they do, have become more complex"); see also Christopher Oster \& Ken Brown, AIG: A Complex Industry, a Very Complex Company, WALL ST. J., Jan. 23, 2002, at C1 (observing, in the context of American International Group, that the problem is "not obfuscation, it's sheer complexity"); Melanie Warner, Can GE Light up the Market Again?, FORTUNE, Nov. 11, 2002, at 108 (discussing General Electric's disclosure problems, which are largely due to structured transactions).

80. David Barboza, Complex El Paso Partnerships Puzzle Analysts, N.Y. Times, July 23, 2002, at $\mathrm{C} 1$ (discussing that "one industry giant, the El Paso Corporation, is growing ever more reliant on deals [using off-balance sheet partnerships] so complex that securities experts call them incomprehensible"); see also David Cay Johnston, Tax Moves by Enron Said to Mystify the I.R.S., N.Y. TiMES, Feb. 13, 2003, at C1 (reporting that "Enron and other big companies have escaped taxes in recent years through financial maneuvers so complex that the Internal Revenue Service has been unable to understand them," and that these transactions, while legal, "create [undisclosed] risks for shareholders").

81. For example, Barboza's article admits that some "Wall Street analysts called the restructuring deals ingenious." Barboza, supra note 80 , at $\mathrm{C} 1$. Nonetheless, even "Wall Street analysts, corporate executives with master's degrees in business administration and, sometimes, even the outside auditors reviewing a company's books" can have trouble understanding corporate disclosure. Liesman, supra note 61 , at $\mathrm{C} 1$.

82. See, e.g., KARL R. POPPER \& KONRAD LORENZ, DIE ZUKUNFT IST OFFEN 74 (Franz Kreuzer ed., 1985) (arguing that some structures, like airplanes, contain so many ideas that they are not comprehensible to any one individual; hence they require collaboration) (translated with the assistance of Oliver von Schweinitz, LL.M. 2003); see also P. B. MEDAWAR, THE LIMITS OF SCIENCE 72-73 (1984) (observing that "modern science is beyond the comprehension of any one mind.... [I]n reality we work not by single minds but by consortia of intelligences, past as well as present; for what we think or do now is a function of what others have thought and done before us - people whose past findings and past errors are part of our own inheritance or understanding. Thus a television set (perhaps the most complicated science-based contraption in everyday use) is not within the effective comprehension of any one mind, for there is no one person who knows the electronics and the glass and vacuum technology and has the know-how of plastic molding to such a degree of proficiency that if some holocaust were to obliterate science and technology so that we had to begin again, this one knowledgeable human being could reinstruct and redirect the activities of those who would in due time reconstruct a television set.").

83. See, e.g., Jeffrey N. Gordon, What Enron Means for the Management and Control of the Modern Business Corporation: Some Initial Reflections, 69 U. CHI. L. REV. 1233, 1238-39 (2002) (noting the failure of investors to draw proper conclusions from their lack of understanding); Hubbard, supra note 31 (observing the failure of Enron's analysts, investment bankers, investors, and lenders to understand the significance of Enron's disclosed information); cf. supra note 81 and accompanying text (observing that even experts can have trouble understanding corporate disclosure). 
perts may be hired to the extent that their costs do not exceed the benefits gained from more fully understanding the complexity, ${ }^{84}$ at some level of complexity those costs will exceed, or at least appear to exceed, any potential gain. This is because the cost of hiring experts is tangible, whereas the benefit gained from fully understanding complex transactions is intangible and harder to quantify. Managers attempting a costbenefit analysis may well give greater weight to the tangible cost and less credence to any intangible benefit. ${ }^{85}$ The more complex the transaction, the higher the costs, and thus the more likely it is that the cost-benefit balance will be out of equilibrium.

Furthermore, market imperfections reduce the value of hiring expert analysts. Professors Healy and Palepu have found, for example, that investment-fund managers who, believing a stock is overvalued, nonetheless follow the crowd will not be blamed if the stock ultimately crashes. ${ }^{86}$ This imperfection is exacerbated by the typically limited time horizon of analyst employment. The analyst may no longer be at the same job if and when a crash occurs, so accountability may be low to begin with. ${ }^{87}$ On the flip side, even where analysts remain at the same job, they might lose their expertise over time. Presumably, they were hired because of their structured-transaction expertise, but structured-transaction markets

84. See, e.g., Daniel R. Fischel, Use of Modern Finance Theory in Securities Fraud Cases Involving Actively Traded Securities, 38 BuS. LAW. 1, 9-10 (1982) (arguing that if inadequate resources are being devoted to processing market information, then the potential for entrepreneurial gain through price arbitrage should provide an incentive for market professionals to invest in processing the information "up to the point where a dollar spent will equal a dollar gained from making superior predictions about the future").

85. The difficulties associated with balancing tangible costs against intangible benefits have been examined extensively in the context of corporate information-system ("IS") decision-making. See, e.g., Edward Rivard \& Kate Kaiser, The Benefit of Quality IS, DATAMATION, Jan. 15, 1989, at 53 (emphasizing the need to educate management, "especially conservative management, on the importance of intangible benefits").

86. Paul M. Healy \& Krishna Palepu, Governance and Intermediation Problems in Capital Markets: Evidence from the Fall of Enron, 17 J. ECON. PERSP. (forthcoming 2003) (noting that nonindex fund managers are rewarded based on fund size and relative performance; fund manager who estimates a stock is overvalued but does not act on this analysis "and simply follows the crowd" will not be rewarded for foreseeing the problems, "but neither will he be blamed for a poor investment decision when the stock ultimately crashes, since his peers made the same mistake"), available at http:// papers.ssrn.com/sol3/delivery.cfm/SSRN_ID325440_code020903590.pdf?abstractid=325440. As a result, "most of the most prestigious investment funds" held Enron stock notwithstanding its disclosure of its conflicted related-party transactions. Id.; see also Stephen M. Bainbridge, Mandatory Disclosure: A Behavioral Analysis, 68 U. CIN. L. REV. 1023, 1038 (2000) (discussing how herd behavior "may have a reputational pay-off even if the chosen course of action fails," and arguing that where "the action was consistent with approved conventional wisdom, the hit to the manager's reputation from an adverse outcome is reduced") (citing Marcel Kahan \& Michael Klausner, Path Dependence in Corporate Contracting: Increasing Returns, Herd Behavior and Cognitive Biases, 74 WASH. U. L.Q. 347,356 (1996)).

87. See John Jacob et al., Expertise in Forecasting Performance of Security Analysts, 28 J. ACCT. \& ECON. 51, 59 (1999) (finding that the average length of analyst-company engagement for sell-side analysts is just "a little over eight years"). 
evolve and, as analysts, they would no longer be employed doing market deals..$^{88}$

These market imperfections are consistent with the results that would be predicted by behavioral psychology. ${ }^{89}$ Complexity heightens ambiguity, which in turn-like the Delphic Oracle - allows people to see what they are already inclined to believe. ${ }^{90}$ Thus, the inclination to follow the crowd is not surprising. Moreover, even for market professionals, it would be difficult to change this behavior. ${ }^{91}$

Additionally, there are practical limitations on understanding complexity even absent herd behavior. The complexity problem affects investors in the originator's securities, yet those investors are not necessarily the same institutions that participate in structured transactions, and thus are less capable of understanding the complexity. ${ }^{22}$ Even when they are the same institutions, the analysts reviewing the disclosure will not

88. Practicality is not all that constrains analysts from engaging in structured deals. A number of SEC rules and regulations require a strict division between transactional activities and investor analysis. For example, SEC Rule 10b5-1 creates a presumption of insider-trading when a securities trader has access to nonpublic information. 17 C.F.R. $\$ 240.10 \mathrm{b5}-1$ (2003). As a result, brokerage houses are required to maintain a "Chinese wall" between research and transactional activities to prevent inadvertent disclosures that would violate securities laws. See id. $\$ 240.14 \mathrm{e}-3$ (b)(2)(ii) (establishing a Chinese wall as an affirmative defense to a claim of misuse of insider information). The Securities Industry Association Best Practice guidelines likewise recommend this separation. See SEC. INDUS. ASS'N, BEST PRACTICES FOR RESEARCH (June 11, 2001), at http://www.sia.com/publications/pdf/ BestPractices_F.pdf. For these reasons, research analysts are usually completely separate from investment bankers. Furthermore, recent possible abuses have motivated politicians to argue for even stricter separation. See, e.g., Henry Kaufman, A Straighter Path for Wall Street, FIN. TimES, Dec. 4, 2002, at 19 (discussing New York Attorney General Elliot Spitzer's recent recommendation that Wall Street firms out-source their research to independent organizations); Brian P. Knestout, So Long, Salomon, KIPLINGER'S PERS. FIN., Jan. 1, 2003, at 58 (discussing Citigroup's plans to spin off a new subsidiary to house its research analysts and retail brokers).

89. Although some have argued that behavioral psychology is not important for analyzing economic market activity, recent scholarship suggests otherwise. Avishalom Tor, The Fable of Entry: Bounded Rationality, Market Discipline, and Legal Policy, 101 MICH. L. REV. 482 (2002).

90. It is reported, for example, that King Croesus of Lydia wanted to make war on Cyrus, but was wary of doing so without heavenly sanction. After singling out the Delphic Oracle as the most reliable, the king's messengers "asked the practical question about the advisability of Croesus' going to war, and received the famous [and famously ambiguous] response that 'Croesus by crossing the Halys would destroy a mighty kingdom." THOMAS DEMPSEY, THE DELPHIC ORACLE: ITS EARLY HISTORY, INFLUENCE, AND FALL 70 (1918). Croesus interpreted this to mean what he wanted to hearthat Cyrus would fall-but in fact the empire that fell was his own. Id. at 71; see also id. at 71, 107 (discussing the historical method of the oracles as sheltering ignorance behind a "studied ambiguity" and vagueness). This same method of response is said also to be used today by fortune tellers. See J. Barkley Rosser, Alternative Keynesian and Post Keynesian Perspectives on Uncertainty and Expectations, 23 J. POST KEYNESIAN ECON. 545, 554-57 (2001) (arguing that uncertainty leads to self-fulfilling mistakes); Tor, supra note 89 , at 105,174 (arguing that the combination of overconfidence and ambiguity leads investors to ignore potentially important information).

91. Tor, supra note 89 , at 560-61 (observing that "debiasing market decisionmakers is typically not a realistic option"); $c f$. Coffee, supra note 2, at 1419 (arguing that securities analysts may fail in any bubble market).

92. Recall that although structured transactions may well be able to be disclosed with sufficient depth and detail to adequately inform a sophisticated investor in the SPE's securities, such disclosure would often go over the head of an ordinary-or even sophisticated-investor in equity securities of the originator. See supra note 31 and accompanying text. 
likely be, and, as discussed, may be prohibited from being, the structured-transaction specialists. ${ }^{93}$

Disclosure of complexity, therefore, has inherent limitations. ${ }^{94}$ Whether or not institutional investors and analysts attempt to hire more structured-transaction experts in reaction to Enron and other corporate failures, the costs involved-as well as market imperfections and behavioral psychology - appear to preclude this from being a complete longterm solution. In a world of complexity, disclosure alone will sometimes be insufficient to remedy the information asymmetry between the originator and its investors.

One therefore might ask whether structured-transaction disclosure could be reduced, in at least certain cases, to easy-to-understand elements, like contingent recourse against the originator. This has an apparent simplicity: assess the risk that an originator will become liable for any contingent liabilities, and then include those liabilities, or a riskdiscounted portion thereof, in the originator's financial statements. This approach, however, would suffer from at least the same problems that a similar approach suffers in derivatives disclosure: it is impossible ex ante to precisely assess the risks, whereas a worst-case disclosure overemphasizes unlikely risks, while potentially ignoring risks that are more realistic. ${ }^{95}$

In addition to these problems, and even outside the derivatives context, assigning a number to contingent liabilities has not proved a panacea. Under generally accepted accounting principles (GAAP), companies have been required since 1975 to include contingent liabilities in their financial statements if it is probable that the liability will be incurred and the resulting loss can be reasonably estimated. ${ }^{96}$ If that loss cannot be reasonably estimated, or if the loss is merely reasonably possible, as opposed to probable, then companies are at least required to disclose the possibility of loss in the footnotes to their financial statements. ${ }^{97}$ Only remote risks are not required to be disclosed..$^{98}$ Nonetheless, and even though Enron's financial statements arguably complied with GAAP, ${ }^{99}$ investors lost because, viewed ex ante, there was only a remote risk in many of the SPE deals that Enron's stock price would dramatically fall at the same time that the SPE-hedged investments would also

93. See supra note 88 and accompanying text.

94. See also infra notes $177-80$ and accompanying text (discussing more generally the failure of professionals as securities gatekeepers).

95. See supra note 66 and accompanying text (noting that Item 305 mandated disclosure of "worst case" derivatives scenarios has those deleterious effects).

96. Fin. ACCounting Standards Bd., Financial ACCOUnting Standard No. 5: AccountING FOR CONTINGENCIES (1975).

97. Id.

98. Id.

99. Cf. supra notes $62-63$ and accompanying text (contending that Enron complied with its disclosure obligations even though investors did not get a clear picture). 
significantly fall in value. ${ }^{100}$ Thus, there are no shortcuts to remedying disclosure's insufficiency. ${ }^{101}$

\section{B. Addressing Disclosure's Insufficiency}

There are three possible ways to respond to this insufficiency. The first is to tolerate insufficient disclosure and its resulting information asymmetry. The second is to proscribe transactions for which the asymmetry exceeds certain bounds. The third is to require supplemental protections to minimize the asymmetry or mitigate its consequences. This article next examines each of these possible responses.

\section{Tolerating Insufficient Disclosure}

Under this response, disclosure would remain the sole paradigm for remedying the information asymmetry between the originator and its investors. At first blush, this response does not seem to be all that different from the current disclosure regime, given that complexity has always existed to some extent. There is, after all, a wide variation of expertise among investors, and no doubt some investors are incapable of fully understanding at least some of the information disclosed. That reality has not been seen as a problem because, in an efficient market, it has been believed that stock prices virtually instantaneously reflect all publicly available information relevant to the value of traded stocks. ${ }^{102}$ Thus, not all investors need to understand any given disclosure. The explanation for how markets can assimilate new information so rapidly stems from

100. See supra notes $12-13$ and accompanying text. To the extent those risks, viewed ex ante, were "reasonably possible" and therefore disclosed in the footnotes to Enron's financial statements, investors also failed to understand the disclosure and, in some cases, even to scrutinize the footnotes. See Anne Tergesen, The Fine Print: How to Read Those Key Footnotes, Bus. WK., Feb. 4, 2002, at 94, 94-95 (noting that investors "could have had a heads-up that all was not quite right at [Enron] long before the bad news broke in October. The source of this information? The footnotes companies are required to publish with their financial statements. ... Footnotes do not make for easy reading, however, and the numbers are often difficult to decipher."). That's not surprising: Did you read this footnote before it was pointed out to you?

101. Even the aspirational goals of $\S 401$ of the Sarbanes-Oxley Act of $2002-$ the section that attempts to maximize GAAP disclosure of contingent liabilities - do not necessarily contemplate assigning a single number to contingent liabilities. Pub. L. No. 107-204, 116 Stat. 745 (codified at 15 U.S.C.A. $\S 7261$ (West Supp. 2002)) (providing that $\S 13$ of the Securities Exchange Act of 1934, 15 U.S.C. $\$ 78 \mathrm{~m}$, is amended by adding at the end thereof a new subsection (j) requiring the SEC to issue "final rules providing that each annual and quarterly financial report required to be filed with the Commission shall disclose all material off-balance sheet transactions, arrangements, obligations (including contingent obligations), and other relationships of the issuer with unconsolidated entities or other persons, that may have a material current or future effect on financial condition, changes in financial condition, results of operations, liquidity, capital expenditures, capital resources, or significant components of revenues or expenses").

102. Charles R.T. O'Kelley \& ROBERT B. Thompson, CORPORATIONS AND Other BusinesS AsSOCIATIONS 170-71 (3d ed. 1999) (referring to this belief as the "semi-strong" form of the efficient market hypothesis). 
the existence of a large number of sophisticated market investors who trade for their own account or for the investors they represent. These professionals track all sources of information affecting the value of stock and act instantaneously to capture the "profit" available by buying stock at the "old" fair price. ${ }^{103}$

But complexity can undermine this result because, with complexity, few if any investors will actually understand the detailed disclosure. ${ }^{104}$ Thus, it is likely that less than a critical mass of investors ${ }^{105}$ will be able to understand the disclosure in order to act to achieve an "efficient" market. ${ }^{106}$ It is even less likely that a critical mass of investors would be able to understand the disclosure in order to act instantaneously to achieve the efficient market. ${ }^{107}$

This can be explained through the efficient-market model proposed by Professors Gilson and Kraakman. To clarify the "operational definition of market efficiency [that] tightly restricts the speed of the market's response to new information by requiring prices to reflect such information 'always'-i.e., very promptly," 108 they reason that there is actually a "continuum of availability" of new information, ranging from nearuniversal distribution of information to information available to only a very few traders. ${ }^{109}$ In the latter case, the focus will be on the time required for the market mechanism to force prices to an efficient equilibrium. ${ }^{110}$ The less "available" new information is, the longer the time

103. Id. at 171 (emphasis added); $c f$. Douglas, supra note 43, at 524 (observing that "even though an investor has neither the time, money, nor intelligence to assimilate the mass of information in the registration statement, there will be those who can and who will do so, whenever there is a broad market [and] [t]he judgment of those experts will be reflected in the market price").

104. Unless, as discussed supra notes 83-93 and accompanying text, institutional investors employ structured-transaction specialists as general analysts. That, however, can be quite costly, and any such specialists so employed would, in the rapidly changing market, lose their expertise over time. See supra notes 83-93.

105. A critical mass in this situation constitutes investors having sufficient trading resources and market influence to move prices.

106. Indeed, recent stock price anomalies have caused many to question even the "semi-strong" form of the efficient market hypothesis discussed above. See, e.g., O'KELLEY \& THOMPSON, supra note 102, at 173-74 (observing that a flaw in this hypothesis may be that markets are dominated by traders whose systematic cognitive biases are not always rational); Gordon, supra note 83, at 1240 (arguing that "Enron disturbs the efficient market hypothesis"); Donald C. Langevoort, Theories, Assumptions, and Securities Regulation: Market Efficiency Revisited, 140 U. PA. L. REV. 851 (1992) (questioning the efficient market hypothesis); Lynn A. Stout, How Efficient Markets Undervalue Stocks: CAPM and ECMH Under Conditions of Uncertainty and Disagreement, 19 CARDozo L. REV. 475, 476-77 (1997) (discussing a contest run by the Wall Street Journal in which, over an eight-year period, professional money managers significantly outperformed random stock picks); Alex Berenson, Scream! Hold on for a Wild Ride, N.Y. TIMES, July 21, 2002, § 4, at 1 (questioning the efficient market hypothesis: "[n] ow that U.S. stocks have fallen in value by almost $\$ 8$ trillion in the last two years even though the economy is still expanding," and quoting Yale economics professor Robert Shiller that "[ $t$ ]he idea that the market is going to reveal fundamental truths is nonsense," and Putnam Investments chief investment officer Jeff Knight that “[t]he market price isn't set by rational analysis").

107. See Ronald J. Gilson \& Reinier H. Kraakman, The Mechanisms of Market Efficiency, 70 VA. L. REV. 549 (1984).

108. Id. at 560 .

109. Id. at 565-66.

110. Id. at 566-67. 
needed for '“full reflection' in price because [the information's] narrower distribution will force a qualitatively more circuitous form of price equilibration."111 Thus, they argue, an innovative investment contract would take the market more time to understand and reach price equilibration than, say, a change in Federal Reserve Board policy. ${ }^{112}$ Similarly, I argue that Enron's SPE-structures were, and indeed many perfectly legitimate structured transactions are, so complex that less than a critical mass of investors can understand them in a reasonable time period, if indeed ever. To that extent, the market will not reach a fully informed price equilibrium, and hence will not be efficient. ${ }^{113}$

Furthermore, the efficient market hypothesis might not even apply to public ${ }^{114}$ or private ${ }^{115}$ bond markets, yet investors in those markets suffer the same information asymmetry discussed in this article. ${ }^{116}$ Although it is possible that detailed disclosure may sometimes be understood and acted on instantaneously by a critical mass of investors, ${ }^{117}$ that result would only be sporadic. Thus, the belief that efficient markets will compensate for disclosure's insufficiency, if ever justified, ${ }^{118}$ certainly is not justified in a world of complexity. ${ }^{119}$

111. Id. at 567 .

112. Id. at 568, 585, 615-16; see also id. at 569 (observing that rapid price equilibration requires "only a minority of knowledgeable traders who control a critical volume of trading activity," but that "[m]any traders are too unsophisticated to make full use of the technical accounting information contained in mandated disclosure reports").

113. I use the term "fully-informed price equilibrium" in the sense proposed by Gilson and Kraakman: the state in which, as a result of the full reflection of information into market price, there is an identity between actual market price and the price that would result if everyone was fully informed. Id. at 558,565 . The market is efficient if, and when, that identity is achieved. Id. at 558 .

114. See Morey W. McDaniel, Bondholders and Stockholders, 13 J. CoRP. L. 205, 242 (1988) ("There is evidence that the market for corporate bonds is not very efficient. For many bond issues, it is not unusual to find infrequent trading activity and large spreads between bid and asked prices.") (citations omitted); Yedidia Z. Stern, A General Model for Corporate Acquisition Law, 26 J. CORP. L. 675,709 (2001) ("[S]tudies show that the bond market is not efficient; and therefore, one cannot expect the market prices to compensate bondholders for the risks to which they are exposed.") I could find no authority in which commentators or experts concluded that debt, as opposed to publicly-traded equity, markets are efficient.

115. Camden Asset Mgmt., L.P. v. Sunbeam Corp., No. 99-8275-CIV, slip op. at 31-36 (S.D. Fla. July 3, 2001) (privately placed Rule 144A-exempt securities, being thinly traded, do not have an efficient market).

116. See supra text accompanying notes $35-36$ (observing that the information asymmetry is between an originator and its shareholders and bondholders).

117. This situation would cause the relevant originator's stock prices to reflect publicly available information.

118. Besides the questions raised by recent stock price anomalies, see supra note 106 and accompanying text, at least one court has held that stock traded on the National Association of Securities Dealers Automated Quotation System (NASDAQ) does not automatically have an efficient market. Stat-Tech Liquidating Trust v. Fenster, 981 F. Supp. 1325, 1346 (D. Colo. 1997). Scholars also have argued that "efficiency is not a market or an exchange attribute, but rather a characteristic of a given security during a given period of time. Even for a given security and time period, efficiency might vary across different information items." See Brad M. Barber et al., The Fraud-on-the-Market Theory and the Indicators of Common Stocks' Efficiency, 19 J. CoRP. L. 285, 290 (1994).

119. Cf. Saul Levmore, Efficient Markets and Puzzling Intermediaries, 70 VA. L. REV. 645, 649-50, 656 (1984) (arguing that market efficiency alone should not dictate policies concerning government regulation of the market without consideration of practical market effectiveness). 
The other possible argument for tolerating insufficient disclosure is that - at least post-Enron-originators engaging in complex transactions may find their share price discounted by investors. ${ }^{120}$ Although ultimately an empirical issue, this suggests that the market is already responding to the problem of complexity. ${ }^{121}$ If so, that would be an unfortunate response because discounting share price based on complexity per se is inefficient. Complexity sometimes is justified. Where investors do not, or cannot, differentiate between justifiable and fraudulent complexity, ${ }^{122}$ however, the market will discount in both cases-thereby driving out otherwise beneficial complexity. ${ }^{123}$ At the same time, fraudulent originators may try to hide complex transactions. In that case, the market would be unable to apply any discount, an even more harmful result.

For these reasons, it would be inexpedient to continue to tolerate disclosure as the sole paradigm for remedying the information asymmetry between originators and investors. The converse proposition, proscribing transactions for which disclosure would be insufficient, is equally problematic, as discussed below.

120. Sheila Muto, Firms Use Synthetic Leases Despite Criticism, WALL ST. J., Feb. 20, 2002, at B6 ("Concern about disclosure prompted an about-face last week by Krispy Kreme Doughnuts Inc., whose previous plan to finance the construction of $\$ 35$ million manufacturing and distribution plant with a synthetic lease [a type of structured transaction] came under fire."); see also Mary Ellen Lloyd, Questioning the Books: Krispy Kreme Takes Steps to Increase Investor Confidence, WALL ST. J., Mar. 8, 2002, at A4 (reporting that trading in Krispy Kreme shares fell as much as fifteen percent following reports criticizing its legal, but off-balance-sheet financing); Ray Smith, Firms Await Ruling on Use of Synthetic Leases, WALL ST. J., Oct. 2, 2002, at B8 (reporting that IDEC Pharmaceuticals Corp., which originally considered using a synthetic lease to finance the development of a new headquarters campus and manufacturing facility, decided instead to raise money through a traditional offering of senior notes). Compare Mark Maremont et al., New Order: Amid Enron's Fallout, and a Sinking Stock, Tyco Plans a Breakup, WALL ST. J., Jan. 23, 2002, at A1 (reporting that Tyco International Ltd., its stock price depressed amid persistent questions about its books, announced plan to split into four separate companies to offer investors "greatly increased simplicity, clarity and transparency;" and that a J.P. Morgan analyst said that dividing the company into smaller pieces should allay investor suspicion about Tyco's complexity because its financial statements are so complex that even veteran investors cannot understand them fully), with Stephen Frothingham, Tyco Abandons Plan to Split into 4, Will Close 24 Plants, WASH. POST, Apr. 26, 2002, at E3 (reporting that Tyco is scrapping its plan to break into four parts), and Gregory Zuckerman, Heralded Investors Suffer Huge Losses with Tyco Meltdown, WALL ST. J., June 10, 2002, at C1 (reporting that Tyco stock has lost substantial value since concerns first surfaced about its complex accounting).

121. One must recognize, of course, that there is no assurance that, as Enron recedes into the past, the market will continue to respond in this fashion. Cf. Claire A. Hill, Why Financial Appearances Might Matter: An Explanation for "Dirty Pooling" and Some Other Types of Financial Cosmetics, 22 DEL. J. CORP. L. 141, 142-43 (1997) (observing that "[c]ompanies using accounting techniques to render themselves more opaque should be punished in the markets [but] ... [t] he real world is dramatically different.").

122. The former being intrinsic, such as the complexity of quantum physics; the latter being complexity intended for obfuscation, such as in a game of three-card Monte. See supra note 41 and accompanying text.

123. See Charles Wilson, Adverse Selection, in 1 The New Palgrave Dictionary of EconomICs 32, 32-33 (John Eatwell et al. eds., 1987) (noting that, in this scenario, "the market allocation is almost always inefficient"); see also infra notes 143-50 and accompanying text (discussing the problem of asymmetric information). 


\section{Proscribing Transactions for Which Disclosure Would Be Insufficient}

If government proscribed or banned transactions for which the information asymmetry exceeds certain bounds, the most immediate consequence potentially would be to eliminate many, if not most, structured transactions. From a societal standpoint, that result would be unfortunate. Even outside of the derivatives context ${ }^{124}$ structured transactions are

widely used and accepted in the United States.... Often, these transactions are efficient means of obtaining funding for their participants while simultaneously achieving accounting, tax and regulatory benefits of various types.... [They] reflect the innovation for which the U.S. capital markets are known[,] . . have many legitimate uses and comprise a significant part of our capital markets. ${ }^{125}$

These transactions are efficient because they transfer investment risks to investors who have the most expertise, or sometimes the most appetite to invest, in those risks. ${ }^{126}$ There is usually a panoply of risks associated with any given originator. In a securitization, for example, the originator separates particular financial assets from those risks by selling or otherwise transferring those assets to a "bankruptcy-remote" SPE. ${ }^{127}$ Investors in the SPE can, therefore, base their investment decisions solely on the risks associated with the transferred assets. ${ }^{128}$ Moreover, even those limited risks "can be borne by providers of credit enhancement or investors in subordinated securities, parties who are in the business of precisely assessing and absorbing such risks." ${ }^{29}$ As a result, the

124. Derivatives transactions are widely used and efficient. See, e.g., Norman Menachem Feder, Deconstructing Over-the-Counter Derivatives, 2002 CoLuM. Bus. L. REV. 677, 678 (observing that derivatives "trade globally and massively" and that "[d]erivatives transactions drive companies today to efficiencies and sophistication unimaginable only two or three decades ago"); Roberta Romano, $A$ Thumbnail Sketch of Derivative Securities and Their Regulation, 55 MD. L. REv. 1, 4-5 (1996) (noting that "[t]he market for financial derivatives is in the trillions of dollars" and, notwithstanding the spectacular losses suffered by certain investors in derivatives, "these instruments serve important economic functions that cannot be overemphasized").

125. In re Enron Corp., No. 01-16034 (AJG) (Bankr. S.D.N.Y. Sept. 21, 2002) (First Interim Report of Neal Batson, Court-Appointed Examiner), at 22 (noting, for example, that "total outstanding mortgage-backed and asset-backed securities in the United States alone exceed \$6 trillion"), available at http://www.enron.com/corp/por/pdfs/InterimReport1ofExaminer.pdf.

126. In addition to obvious accounting and tax advantages, the efficiency of securitization transactions, for example, is most evident when considering the specialties of the parties involved. For example, a bank may specialize in originating mortgage loans. Although this specialty enables the bank to manage the risks associated with individual borrowers, another firm may be better suited to manage or bear large financial risks generally. See Hill, Securitization: A Low-Cost Sweetener for Lemons, supra note 22, at 1094-96 (explaining the benefits securitization can offer both to financial management and the origination and collection of financial assets). Securitization transactions thus efficiently shift risks away from the originators. See supra notes 19-22 and accompanying text.

127. Schwarcz, The Alchemy of Asset Securitization, supra note 17, at 135.

128. Id. at 151 (explaining that "[b]ecause a bankruptcy remote structure separates the source of payment of the SPV's securities from the risks associated with the originator, the need to monitor the originator's financial condition is largely eliminated").

129. Id. Interestingly, this creates a paradox of sorts. By separating out and matching risks with investors having the most information about those risks, structured transactions actually can reduce 
universe of investors interested in investing in those assets greatly expands, as witnessed, for example, by the tremendous success of organizations like the Federal National Mortgage Association ("Fannie Mae")130 in helping banks to securitize home mortgage loan portfolios in order to increase their liquidity and enable them to make loans to new homeowners. $^{131}$

The efficiency achieved by allocating risks in structured transactions is, in fact, sometimes imitated by companies in a larger context through a "corporate split." 132 In these transactions, a company whose business consists of profitable and unprofitable product lines restructures by transferring assets associated with the profitable product line to a newly created affiliated company (Newco). Newco is owned by the same shareholders who own the original company (Oldco), now shorn of the assets transferred to Newco. ${ }^{133}$ The result is that the combined stock price of Newco and Oldco exceeds the stock price of the original company. ${ }^{134}$ The price increase reflects a higher-valued allocation of risks with assets. ${ }^{135}$ Because corporate splits raise their own sets of legal issues, ${ }^{136}$ however, they are not substitutes for structured transactions.

Another reason that government should not want to proscribe transactions as a means of controlling information asymmetry is that any such proscriptions would create regulatory arbitrage incentives: parties would want to make transactions appear to meet the regulatory require-

information asymmetry. This article does not purport to balance this reduction in information asymmetry with the increased information asymmetry resulting from more complex transaction structures.

130. Although originally created as a government agency to establish a national secondary market for home mortgages, Fannie Mae is now a privately-managed corporation, though subject to certain governmental oversight. See FANNIE MAE, Understanding FANNIE MAE AS a SECURITIES IsSUER, at http://www.fanniemae.com/mbs/understanding/index.jhtml? $\mathrm{p}=$ Mortgage-Backed+Securities (last modified July 23, 2003).

131. Thus, "Fannie Mae has played a vital role in the growth and development of today's expanding secondary mortgage market by introducing major, innovative [securitized] products ... [which] offer investors high-quality investments with attractive yields to fit their portfolio needs or investment strategies." FANNIE MAE, BASICS OF FANNIE MAE MBS, at http://www.fanniemae.com/mbs/ mbsbasics/market/structure.jhtml? $p=$ Mortgage-Backed+Securities (last modified July 21, 2003). That, in turn, makes it "possible for low-, moderate-, and middle-income families to buy homes of their own." FANNIE MAE, ABOUT FANNIE MAE, at http://www.fanniemae.com/aboutfm/index.jhtml?p= About+Fannie+Mae (last visited Oct. 16, 2003); see also Structured Finance, supra note 17, § 1:2 (discussing the history of Fannie Mae and the Government National Mortgage Association in providing liquidity through the capital markets); Schwarcz, The Alchemy of Asset Securitization, supra note 17, at 153-54 (discussing how securitization increases bank lending to small businesses by transforming a bank's existing loan portfolio into asset-backed securities, which then can be easily sold to capital market investors, enabling the bank to use the sale proceeds for making new loans).

132. See generally Steven L. Schwarcz, Rethinking a Corporation's Obligations to Creditors, 17 CARDOZO L. REv. 647, 678-82 (1996) [hereinafter Schwarcz, Rethinking a Corporation's Obligations to Creditors] (discussing corporate splits generally, including the highly publicized "Marriott split").

133. This is normally accomplished by a stock split or dividend in which shareholders of Oldco receive shares of Newco in an amount proportional to their holdings of Oldco stock. Id. at 678 n.131.

134. See Glenn Collins, Hungry Shareholders vs. Wary Managers, N.Y. TIMES, Nov. 4, 1995, at A2.

135. Schwarcz, Rethinking a Corporation's Obligations to Creditors, supra note 132 , at $678-79$ \& n.132.

136. See id. at $678-82$. 
ments. ${ }^{137}$ For example, if government were to proscribe transactions for which the information asymmetry exceeded a threshold level, then parties would attempt to structure those transactions in ways that appear to reduce the asymmetry, as measured by the regulatory ban, below that threshold. ${ }^{138}$ The end result could be socially undesirable: the regulatory proscription is effectively bypassed, but the overall transaction costs rise due to the expenses of lawyers and other advisors hired for that purpose. ${ }^{139}$

For these reasons, regulators should not want to proscribe structured transactions as a means of controlling information asymmetry. ${ }^{140}$

\section{Requiring Supplemental Protections}

The foregoing analysis has shown that although the long-standing belief that markets will compensate for disclosure's insufficiency is not justified in a world of complexity, it would be socially harmful to ban complex transactions merely because of the information asymmetry. The third response, therefore, is to consider whether disclosure can be buttressed by cost-effective, supplemental protections that minimize that asymmetry or mitigate its consequences.

137. Regulatory arbitrage occurs when parties design transactions - in this case, financial transactions - to try to "reduce costs or capture profit opportunities created by differential regulations or laws." Frank Partnoy, Financial Derivatives and the Costs of Regulatory Arbitrage, 22 J. CORP. L. 211, 227 (1997).

138. The propensity to try to capitalize on regulatory arbitrage is well illustrated by the motto of J.P. Morgan Securities' Structured Finance-Tax Products/Derivatives Vehicles Group (the "Group"): "Anywhere you see a rule, you see an opportunity." Interview with Ajay Kumar Mehrotra, former Associate in that Group, in Durham, N.C. (Dec. 13, 2002).

139. A more nuanced approach might be to proscribe transactions for which disclosure would be insufficient only where transaction costs and other externalities outweigh any public good. This approach, however, appears impractical because, given the indeterminateness of balancing transaction costs and other externalities against public good, it would be difficult to identify these transactions ex ante. For example, the public good itself, as a concept, is ephemeral. See, e.g., Cass R. Sunstein, $\mathrm{Na}$ ked Preferences and the Constitution, 84 CoLUM. L. REV. 1689, 1702 (1984) (observing that "over time ... the category of public values expands and contracts"). Thus, in the heyday of Reaganomics, "[i]ncreased price competition was considered a public good because of its presumed beneficial effects upon consumer choice, economic efficiency, resource allocation and growth." Timothy A. Canova, The Transformation of U.S. Banking and Finance: From Regulated Competition to Free-Market Receivership, 60 BROOK. L. REV. 1295, 1296 (1995). At other times, redistributive schemes have been touted as promoting the public good. See Robert C. Farrell, Legislative Purpose and Equal Protection's Rationality Review, 37 VILL. L. REV. 1, 48 (1992).

140. The reader should distinguish the foregoing analysis from the related question of the extent to which structured transactions should be accounted for, from the originator's standpoint, as offbalance sheet. That question is presently governed by GAAP, and its answer turns on such factors as the degree of control that the originator has over the SPEs used in the structured transaction and the extent to which independent third parties make equity investments in those SPEs. FIN. ACCOUNTING STANDARDS BD., FINANCIAL ACCOUNTING STANDARD NO. 94 (1987). Although off-balance sheet structured transactions raise more difficulties for disclosure, the analysis of this Part II.B.2, including Examiner Batson's observations, supra note 125 and accompanying text (describing structured transactions as being an efficient and legitimate means of obtaining funding that is widely used and accepted in the U.S.), are all made in the context of the transactions being off-balance sheet. 
In this context, it should be emphasized that any such supplemental protections would be in addition to, not in place of, disclosure. Even insufficient disclosure provides value by reducing information asymmetry, ${ }^{141}$ and disclosure has other justifications beyond the asymmetric information problem. ${ }^{142}$

In thinking about supplemental protections, it is useful to take into account economic theory on asymmetric information, especially that dealing with the so-called Lemons problem. Economists have asked: How do transactions ever occur if the seller has more information than the buyer, and the information disparity cannot be cured (at least at reasonable cost)? Why would a buyer ever be willing to enter into a transaction? This, of course, is precisely the problem of complexity.

The Lemons problem was introduced and first systematically studied by economist George Akerlof, ${ }^{143}$ using the crude, but intuitive, example of the used-car market:

From time to time one hears either mention of or surprise at the large difference between new cars and those which have just left the showroom.... The individuals in this market buy a new automobile without knowing whether the car they buy will be good or a lemon. But [overall market statistics enable them to] know that with [a high] probability it is a good car and with [a lower] probability ... it is a lemon.... After owning a specific car, however, for a length of time, the car owner can form a good idea of the quality of this machine; i.e., the owner assigns a new probability to the event that his car is a lemon. This estimate is more accurate than the original estimate. An asymmetry in available information has developed: for the sellers now have more knowledge about the quality of a car than the buyers. But [absent a solution] good and bad [used] cars must still sell at the same price-since it is impossible for a buyer to tell the difference between a good [used] car and a bad [used] car. ${ }^{144}$

Akerlof argues that it is up to the seller to achieve a solution to this problem of quality uncertainty: "those [merchants] who can identify used cars in our example and can guarantee the quality may profit." 145 One obvious solution is guaranties, ${ }^{146}$ such as warranties on the sale of

141. This assumes that the value of such insufficient disclosure will exceed its cost. Whether that assumption will be true in all cases is beyond the scope of this article.

142. Disclosure also can be seen as a means to break the management monopoly over corporate information, and is necessary because separation of ownership and control can cause managers to maximize their own utility at the expense of investors. JAMES D. COX, ROBERT W. HILLMAN \& DONALD C. LANGEVOORT, SECURITIES REGULATION 358 (3d ed. 2001).

143. In fact, Akerlof won the 2001 Nobel Prize in economics for his work on this problem. See Press Release, The Nobel Foundation, 2001 Bank of Sweden Prize in Economic Sciences in Memory of Alfred Nobel (Oct. 10, 2001), at http://www.nobel.se/economics/laureates/2001/press.html (last visited Oct. 23, 2003).

144. Akerlof, supra note 1, at 489-90 (emphasis added).

145. Id. at 496 (emphasizing that "these skills are equally necessary-both to be able to identify the quality of inputs and to certify the quality of outputs").

146. Id. at 499. 
goods,${ }^{147}$ in order to shift the risk from the buyer to the seller. Other institutions that have arisen to counteract this problem are brand-name goods, ${ }^{148}$ chains (such as hotel and restaurant chains), ${ }^{149}$ and governmental and private-sector certification through, for example, licensing. ${ }^{150}$

Brand-name goods and chains, however, appear to be indirect guaranties made by placing the reputation of the goods or the chain as a hostage. ${ }^{151}$ If the goods are defective, or the chain provides inferior quality, then the reputation suffers. Therefore, one can view the possible solutions as being in two categories: protect the buyer of (in the context of this article) securities either by (i) direct or indirect guaranties of their value or (ii) providing governmental and/or private-sector certification of their quality. I examine these protections in turn.

Guaranties. The first approach to protecting a buyer of securities is to provide direct or indirect guaranties of the value of the securities. Direct guaranties would not work to the extent that issuers of securities, by the very nature of the securities, are already making themselves liable to investors for repayment. ${ }^{152}$ Nonetheless, there may be ways to create indirect guaranties, such as bonds or hostages, to be sacrificed in the event of management exploitation of the information asymmetry.

An obvious way is to provide for case-by-case ex post review of, and some form of punishment for, management exploitation of the information asymmetry, or to otherwise use ex post review as a sort of bond that substitutes for ex ante screening of the transaction. To the extent the exploitation amounts to fraud, this review is already performed by administrative agencies, such as the SEC, and through litigation in courts. ${ }^{153}$ In

147. See, e.g., U.C.C. $\$ \S 2-312$ to -315 (1998) (providing for warranties on the sale of goods).

148. Akerlof, supra note 1 , at 499.

149. Id. at 500 .

150. Id.

151. See id.

152. In the case of debt securities, the originator is liable as a recourse obligation, and even equity securities give investors residual claims against the originator. See, e.g., Schwarcz, Rethinking a Corporation's Obligations to Creditors, supra note 132, at 667 . Moreover, any scheme to increase the priority of equity investors' residual claims would be problematic: making those claims pari passu with the originator's debt claims would dilute recovery on the latter, merely shifting some of the losses from the originator's equity investors to the originator's debt investors-whereas keeping the residual claims subordinate to debt claims would not improve the position of equity investors.

153. See Bernard S. Black, The Legal and Institutional Preconditions for Strong Securities Markets, 48 UCLA L. REV. 781, 787 (2001) (describing how the United States has partially solved the "information asymmetry problem through a complex set of laws and private and public institutions that give investors reasonable assurance that the issuer is being (mostly) truthful"). Rule 10b-5 under the Securities Exchange Act of 1934 (the "1934 Act"), for example, makes it unlawful for any person in connection with the purchase or sale of any security:

(a) To employ any device, scheme, or artifice to defraud, (b) To make any untrue statement of a material fact or to omit to state a material fact necessary in order to make the statements made, in the light of the circumstances under which they were made, not misleading, or (c) To engage in any act, practice, or course of business which operates or would operate as a fraud or deceit upon any person, in connection with the purchase or sale of any security.

17 C.F.R. $§ 240.10$ b-5 (2003). 
those cases, the punishment includes civil liability and possible criminal prosecution of management. ${ }^{154}$

An ex post approach, though, is a blunt instrument. It poorly filters bad transactions because they will be discovered only after they occur. ${ }^{155}$ And it creates uncertainty for, and imposes a chilling effect on, good transactions because of the possibility that an originator with complex transactions - even those viewed ex ante as justifiable - can fail. ${ }^{156}$ Management then would have to argue ex post, possibly in the face of adverse publicity and zealous government officials, that the failed complex transactions were not fraudulent. ${ }^{157}$

Certification of Quality. The second approach to protecting a buyer of securities is certification of their quality either by the government or reputable private-sector entities. Governmental certification is a form of merit regulation, ${ }^{158}$ and can be expensive. In the context of the original enactment of the federal securities laws, it was explicitly rejected as unworkable. ${ }^{159}$ At that time, there was significant controversy over whether federal law should focus on requiring full disclosure or on imposing governmental merit analysis. ${ }^{160}$ State "blue sky" laws provided for both. ${ }^{161}$ Nonetheless, Congress, "[a]fter considerable debate, ... decided not to follow the pattern of the state acts and eschewed the idea of a merit approach, opting instead for a system of full disclosure." 162 There is little

154. Securities fraud causes of action, for example, may be criminal, civil, or administrative in nature. 17 C.F.R. $\S 202.5$ (b). For an overview of possible civil, criminal, and administrative actions taken in the event of securities law violations, see Alyssa Hall \& Adam M. Schoeberlein, Securities Fraud, 37 AM. CRIM. L. REV. 941 (2000). See also William S. Lerach, The Private Securities Litigation Reform Act of 1995-27 Months Later: Securities Class Action Litigation Under the Private Securities Litigation Reform Act's Brave New World, 76 WASH. U. L.Q. 597 (1998) (discussing class action lawsuits as a possible response to management exploitation of information asymmetry).

155. See generally Steven L. Schwarcz, Rethinking Freedom of Contract: A Bankruptcy Paradigm, 77 TEX. L. REV. 515 (1999) (discussing problems associated with ex post approach).

156. Cf. id. at 592 (arguing that ex post judicial reassessment of a troubled debtor's determination whether offered-liquidity is likely to help the debtor rehabilitate may cause the "liquidity [to] dry up because few liquidity providers would be willing to be second-guessed"); Schwarcz, Use and Abuse of Special Purpose Entities, supra note 5, at 1313 (arguing that Enron's management and its accountants were, in many cases, making exquisitely fine judgment calls, and that although, in retrospect, they may have misjudged, the culpability of their actions should be assessed ex ante, not ex post).

157. It is human nature to infer the obvious, though incorrect, cause from a dramatic event. $C f$. DON HEROLD, THE HAPPY HYPOCHONDRIAC 64 (1962) (a humorous book in which, after surviving numerous imagined scares, a hypochondriac ultimately dies of old age; but on his gravestone appear the words, "See, I told you I was no hypochondriac.").

158. Indeed, at a fundamental level, government regulation and government certification are related concepts. The government effectively certifies as "legal" only those transactions that comply with the regulation.

159. See Knauss, supra note 42 , at 615 (arguing that " $[t]$ he main argument for disclosure was that a regulatory approach was not administratively practical").

160. See generally 1 HAZEN, supra note $49, \S 1.2$, at $21-34$ (tracing early developments in securities regulation).

161. 1 id. $\S 1.2[2]$, at 26 (observing that "the state blue sky laws not only focused on providing investors with full disclosure of relevant facts, but also required that all securities registered thereunder 'qualify' on a merit basis, evaluating the substantive terms of the securities to be offered").

162. 1 id. $\$ 1.2[3][\mathrm{A}]$, at 27-28. Part of Congress's rationale was that a disclosure-approach would avoid any implication that, by approving issuance of a security, the government was guaranteeing its 
current literature on government certification of securities quality because, until recently, disclosure was seen as the complete answer.

Should we now reconsider some form of substantive governmental merit regulation? One might argue, based on the historical experience of the state blue sky laws, that merit regulation is ineffective and not worth its cost. ${ }^{163}$ But it is unclear whether those laws were a fair test of merit regulation. Although the "blue sky laws proved to be relatively ineffective in stamping out securities frauds, especially on a national level,"164 such ineffectiveness "should not condemn this type of [substantive] control. The States had effective power only within their boundaries. And the amazing interstate complexity of the security business made action by the separate States conspicuously ineffective."165

It nonetheless continues to appear that if other supplemental protections are available, governmental merit regulation would not be costeffective. Such merit regulation would, by definition, rely on government employees to assess the quality of securities. ${ }^{166}$ It is doubtful that these employees would do a better job than private-sector analysts, who already perform this function for investors. ${ }^{167}$ The private-sector analysts are likely to be more capable, on average, and also more accountable, because the government generally pays lower salaries than the private sector $^{168}$ and government employees are often harder to fire if they perform poorly. ${ }^{169}$ Furthermore, the imposition of governmental merit regu-

soundness. James M. Landis, The Legislative History of the Securities Act of 1933, 28 GEO. WASH. L. REV. 29, 30, 34 (1959-1960).

163. The perceived inefficiency of merit regulation is predicated on a belief in the efficiency of disclosure as a corrective mechanism. Under this theory, full disclosure obviates any need for merit regulation, by increasing corporate transparency. Merit regulation is thus redundant and not costeffective. See Steven L. Schwarcz, Private Ordering of Public Markets: The Rating Agency Paradox, 2002 U. ILL. L. REV. 1, 21 [hereinafter Schwarcz, Private Ordering of Public Markets] (explaining this argument but recognizing that "[t]he historical rationale for full disclosure ... is not always applicable"). Additionally, merit regulation assumes an ability to assess ex ante the quality of a security. Even assuming low-quality securities can be identified, "it is not evident why a disclosure requirement would not have been equally efficacious at alerting consumers to the dangers of a particular issue, while not foreclosing the market entirely to consumers willing to take the risks in order to get a chance at the rewards." Jonathan R. Macey \& Geoffrey P. Miller, Origin of the Blue Sky Laws, 70 TEX. L. REV. 347, 395 (1991). But cf. JOSEPH C. LONG, BLUE SKY LAW $\$ 1: 56$ (2002) (arguing that because the federal securities-law scheme does not preempt state blue sky laws, see 15 U.S.C. $\$ 77 \mathrm{r}(2002)$, enactment of the federal scheme was not a complete rejection of merit regulation).

164. 1 HAZEN, supra note $49, \S 1.2$, at 26.

165. Douglas, supra note 43 , at 531 .

166. To the extent government delegates this job to the private sector, that would be a form of private ordering, discussed infra notes 171-80 and accompanying text. For a general discussion of this topic, see Steven L. Schwarcz, Private Ordering, 97 Nw. U. L. REV. 319 (2002).

167. See infra notes $177-80$ and accompanying text (discussing the role of securities analysts and other professionals as gatekeepers).

168. For a thorough discussion of the correlation between public- and private-sector salaries, see Craig A. Olson et al., The Effects of Local Market Conditions on Two Pay-Setting Systems in the Federal Sector, 53 INDUS. \& LAB. REL. REV. 272 (2000). A possible reason that private firms pay more is that they have to rely more heavily on reputation than government regulators, which operate through fiat.

169. See, e.g., Kathryn Moss et al., Unfunded Mandate: An Empirical Study of the Implementation of the Americans with Disabilities Act by the Equal Employment Opportunity Commission, 50 U. KAN. 
lation and resulting duplication of these functions not only would be inherently inefficient but, perversely, could actually undermine the market for private securities analysts, thereby eliminating any reduced information asymmetry resulting from their analysis. ${ }^{170}$

This article, therefore, next examines the extent to which privatesector certification of quality would be sufficient to reduce this information asymmetry. Private-sector certification of quality already exists, and it has not proved effective in the face of complexity. For example, investors already demand ratings by nongovernmental rating agencies on the safety of debt securities. ${ }^{171}$ But rating-agency certification, while valuable, has not been a panacea. Ratings are presently only given on debt, not equity, securities. ${ }^{172}$ Ratings also do not purport to certify against fraud. ${ }^{173}$ Possibly for this reason the rating agencies failed to predict Enron's demise, and Enron's debt was not downgraded below investment grade until days before its bankruptcy. ${ }^{174}$ Nor would it appear to be costeffective for rating agencies to certify against fraud. ${ }^{175}$

An indirect form of private-sector certification of quality is also performed by outside professionals involved in the originator's issuance of securities. ${ }^{176}$ Traditionally, a professional gatekeeper - such as an inde-

L. REV. 1, 71 (2001) (quoting an EEOC staff member: "It is next to impossible ... to fire someone [in the federal government] for poor performance. Performance is much too difficult to establish. You cannot even set up numerical performance goals for investigators."); see also Cleveland Bd. of Educ. v. Loudermill, 470 U.S. 532, 542-43 (1985) (holding that federal agencies must comply with strict due process standards when terminating employees "for cause"); David R. Riemer, Government As Administrator vs. Government As Purchaser: Do Rules or Markets Create Greater Accountability in Serving the Poor?, 28 FORDHAM URB. L.J. 1715, 1719 (2001) (concluding that because the civil service system lacks the tools to fire the mediocre or reward the stars, "the level of competence in any governmental structure is dismal").

170. I next argue that the information asymmetry caused by complexity exists, and will persist, notwithstanding scrutiny by private-sector securities analysts. That argument is not inconsistent with the text above; analyst scrutiny may reduce, but does not remove, the information asymmetry.

171. Schwarcz, Private Ordering of Public Markets, supra note 163, at 3 (citing Steven L. Schwarcz, The Universal Language of Cross-Border Finance, 8 DUKE J. COMP. \& INT'L L. 235, 251-52 (1998)); see also Frank Partnoy, The Siskel and Ebert of Financial Markets?: Two Thumbs Down for the Credit Rating Agencies, 77 WASH. U. L.Q. 619 (1999).

172. Schwarcz, Private Ordering of Public Markets, supra note 163, at 6 (citing Steven L. Schwarcz, The Universal Language of Cross-Border Finance, 8 DUKE J. COMP. \& INT'L L. 235, 253 n.82 (1998)).

173. Id. (citing Steven L. Schwarcz, The Universal Language of Cross-Border Finance, 8 DUKE J. COMP. \& INT'LL. 235, 252 n.76 (1998)).

174. Hearings, supra note 53, at 17 (testimony of Frank Partnoy).

175. Rating agencies presently do not have the resources, such as investigative staff, to investigate possible fraud of the companies whose securities they are rating. Interview with John Rutherford, Jr., President and Chief Executive Officer, Moody's Corporation, and Raymond W. McDaniel, President, Moody's Investors Service, Inc., in Durham, N.C. (Sept. 24, 2002). If a rating agency were to obtain such resources, there is concern that the greatly increased staffing and size would bureaucratize the ratings process (making individual staff members feel less personally responsible), with unintended consequences. Id. Furthermore, this increased staffing, along with the premium required to offset litigation and settlement costs resulting from failures to discover fraud, would significantly increase the cost of ratings, potentially undermining their economic vitality.

176. Another indirect form of private-sector certification of quality is management's signaling, to investors, that they believe in the originator. Traditionally, management does this by investing in the originator's stock and by accepting stock options as compensation. A HANDBOOK OF BUSINESS LAW 
pendent auditor, securities analyst, investment banker, or, at times, a lawyer - "represents to the market ... that it has evaluated the issuer's product and good faith and that it is prepared to stake its reputation on the value of the innovation."177 Post-Enron, however, there has been much discussion about the failure of professionals as gatekeepers. ${ }^{178}$ This failure may be rooted in the basic conflict of interest faced by gatekeepers: a "desire to be perceived as credible and objective may often be subordinated to [a] desire to retain and please . . clients." 179 As a result, the public has lost confidence, at least temporarily, in traditional gatekeeper mechanisms. ${ }^{180}$

The foregoing discussion suggests that certification of the quality of securities, whether by government or third parties, cannot fully solve the asymmetric information problem in a cost-effective manner. I next inquire whether some lesser form of certification could do so.

Certification need not go so far as merit regulation. There may be less costly approaches, perhaps certifying not quality but a lesser, observable standard that may help to determine quality. One such approach would be to mitigate the conflicts of interest that create the risk that an originator's management will structure transactions contrary to the interests of investors. ${ }^{181}$

TERMS 570 (Bryan A. Garner ed., 1999). This certification did not prove reliable in Enron, however, and is unlikely to be reliable because complexity impairs the ability of nonconflicted managers to fully judge the merits of the transaction. Cf. infra notes 214-16 and accompanying text (arguing, for this reason, that approval of conflicted "disclosure-impaired" transactions by disinterested directors could backfire).

177. Gilson \& Kraakman, supra note 107, at 619.

178. See, e.g., Coffee, supra note 2, at 1404-05; see also Hearings, supra note 53, at 15-18 (testimony of Frank Partnoy) (recommending inquiry into the roles of the "major financial market 'gatekeepers' involved with Enron: accounting firms, banks, law firms, and credit rating agencies").

179. Coffee, supra note 2, at 1408 .

180. Regulatory approaches might be able to minimize these conflicts of interest by, for example, requiring that at least certain professional gatekeepers - e.g., independent auditors-be paid directly through public funding. But even that approach would be imperfect. If gatekeepers are selected by companies but paid by the public, then the gatekeepers would still want to please their clientcompanies; whereas choosing and paying gatekeepers through public-sector mechanisms would merely constitute another form of government merit regulation, discussed above. The insidious effect of gatekeeper conflicts of interest also might be reduced to some extent by requiring - at least for auditors - that opinions comply with principle-based, as opposed to rule-based, standards. That presumably would require the auditor to exercise independent judgment based on principles, instead of merely certifying that financial statements comply with the technical rules of GAAP, which sometimes can be manipulated. Id. at 1416-17; see also Peter Jeffrey, International Harmonization of Accounting Standards, and the Question of Off-Balance Sheet Treatment, 12 DUKE J. COMP. \& INT'L L. 341 (2002) (comparing GAAP's rule-based standards with the principle-based standards of IAS (International Accounting Standards)); Floyd Norris, An Old Case Is Returning to Haunt Auditors, N.Y. TIMES, Mar. 1, 2002, at C1 (noting that SEC Chairman Harvey Pitt has been citing United States v. Simon, 425 F.2d 796 (2d Cir. 1969), for the proposition that auditors sometime will be held to standards beyond GAAP). For a discussion of these and other possible models for reform, see Coffee, supra note 2, at $1416-17,1420$.

181. I am not advocating mitigating all conflicts, only those present in disclosure-impaired transactions. Corporation law recognizes that all conflicts of interest cannot be entirely eradicated, and permits transactions in the face of conflicts of interest if decisions are made or ratified by nonconflicted parties. In Delaware, for example, although courts can review the fairness of interested-party 
To understand this risk, consider the problem in Enron. Enron's investors were unable to rely on Enron management in setting up SPE structures for Enron's benefit. ${ }^{182}$ Indeed, the Powers Report finds evidence that Chief Financial Officer Andrew Fastow and certain other Enron executives either overruled or intimidated employees who felt that the SPE transactions were detrimental to Enron and its shareholders. ${ }^{183}$ These manipulations thrived because of a tangled web of conflicts of interest: senior Enron executives, most notably Fastow, served as the SPEs' principals, receiving such massive amounts of compensation and returns as to potentially skew their loyalty in favor of the SPEs. ${ }^{184}$ Nonconflicted management, on the other hand, may have resisted or at least questioned Enron's entering into dubious structured transactions that, if failed, could (and did) bring down the company. ${ }^{185}$

Regulation ${ }^{186}$ could be used to this end by restricting or, as shown below, ideally by prohibiting conflicts in complex transactions for which disclosure would be insufficient (disclosure-impaired transactions). ${ }^{187}$

transactions, Oberly v. Kirby, 592 A.2d 445, 466 (Del. 1991), ratification by independent directors or shareholders reinstates the traditional business judgment rule, under which courts will not undertake to second-guess the expediency of business transactions so authorized. See Sinclair Oil Corp. v. Levien, 280 A.2d 717, 720 (Del. 1971) ("A board of directors enjoys a presumption of sound business judgment, and its decisions will not be disturbed if they can be attributed to any rational business purpose. A court under such circumstances will not substitute its own notions of what is or is not sound business judgment."); Orman v. Cullman, 794 A.2d 5, 23 (Del. Ch. 2002); Lewis v. Vogelstein, 699 A.2d 327, 336 (Del. Ch. 1997); Gries Sports Enters., Inc. v. Cleveland Browns Football Co., 496 N.E.2d 959, 963-64 (Ohio 1986) ("The rule is a rebuttable presumption that directors are better equipped than the courts to make business judgments and that the directors acted without self-dealing or personal interest and exercised reasonable diligence and acted with good faith."). U.S. securities law often takes the same approach. See, e.g., Securities and Exchange Commission (SEC), Comments of Securities Industry Association on SR-NASD-2002-21 and SR-NYSE-2002-09, 1321 PLI/CORP. 475, 477-78 (2002) ("We agree with the premise that, as a general principle, disclosure is a better approach to managing real or apparent conflicts of interest than prescriptive prohibitions, which can be both overly complex and subject to evasion"). Thus, rather than prohibiting conflicts of interest in corporate transactions, Item 404(a) of Regulation S-K mandates disclosure of any transaction in which any of the following had a "direct or indirect material interest": (1) directors and executive officers; (2) nominees for election as directors; (3) holders of more than five percent of any of the registrant's voting securities; or (4) "any member of the immediate family of any" of these persons. 17 C.F.R. $\S 229.404$ (a) (2003).

182. Powers Report, supra note 6.

183. Id. at 18, 21, 144, 166-67 (discussing allegations that Enron-CFO Fastow, on behalf of the LJM-SPEs, pressured Enron personnel to give favorable terms to such SPEs, even though such terms are not in the best interests of Enron shareholders).

184. Id. at $41,60,77,102$. These Enron executives also may have received financial windfalls in connection with the termination of SPEs. Id. at 60-61. For example, the unwinding of the Rhythms transaction (with respect to which "Enron did not seek or obtain a fairness opinion") "resulted in a huge windfall" to that SPE, and thus to the Enron executives associated with it. Id. at 89.

185. Cf. Coffee, supra note 2, at 1403 (suggesting Enron's management conflicts of interest as key factors in its downfall).

186. Recall that regulation is fundamentally a form of government certification - the government effectively certifies as "legal" only those transactions that comply with the regulation. See supra note 153 and accompanying text.

187. I show infra notes 198-201 and accompanying text how disclosure-impaired transactions can be identified. Note that the insufficiency should be judged from the standpoint of the originator's investors, the audience primarily affected by the information asymmetry. But should that audience be judged by the average investor, the average institutional investor, or perhaps even on the average se- 
Restrictions may require active and ongoing monitoring of conflicts, ${ }^{188}$ which can be difficult to manage. In Enron, for example, senior executives seemed to have a somewhat casual approach toward compliance with the conflicts-of-interest requirements of Enron's Code of Conduct. ${ }^{189}$ The required Board approval of these types of conflicts was not always obtained. ${ }^{190}$ Even where approval was obtained, the monitoring required as a condition to approval was not always properly implemented. ${ }^{191}$

More tellingly, the Powers Report concludes that "a conflict ... that could be managed only through so many controls and procedures should not have been approved in the first place," ${ }^{192}$ explaining that

perhaps the most basic reason that controls failed was structural. Most of the controls were based on a model in which Enron's business units were in full command of transactions and had the time and motivation to find the highest price for assets they were selling. In some cases, transactions were consistent with this model, but in many of the transactions the assumptions underlying this model did not apply. ${ }^{193}$

Restricting conflicts of interest, short of prohibiting them, therefore may not always be feasible. But a rule prohibiting material conflicts of interest ${ }^{194}$ in disclosure-impaired transactions (postulated rule) should be

curities analyst? The efficient market hypothesis suggests that disclosure understood only by securities analysts and sophisticated institutional investors nonetheless would be sufficient. See supra Part II.A. On the other hand, the "average investor" standard is more in keeping with the SEC's traditional requirements. Section 13(j) of the Securities Exchange Act of 1934 defines "reasonable detail" as "such level of detail ... as would satisfy prudent officials in the conduct of their own affairs." 15 U.S.C.A. $\$ 78 \mathrm{~m}(\mathrm{~b})(7)$ (2003). Recently, in response to the passage of the Sarbanes-Oxley Act of 2002, Pub. L. No. 107-204, 116 Stat. 745 (codified in scattered sections of 11, 15, 18, 28, and 29 U.S.C.A.), the SEC announced new disclosure guidance for off-balance sheet arrangements. 68 Fed. Reg. 5982 (Feb. $5,2003)$. Section III.E.2 of the final rule states that " $[t]$ he information should not be presented in such a manner that only an accountant or financial analyst or an expert on a particular industry would be able to fully understand it." Id. at 5991 (emphasis added).

188. All references in this article to "conflicts" mean material conflicts. See infra note 194 and accompanying text.

189. Enron's Code of Conduct provided, in relevant part, that no officer or employee should "[o]wn an interest in or participate, directly or indirectly, in the profits of any other entity which does business with ... the Company, unless such ownership or participation has been previously disclosed in writing to the Chairman of the Board and Chief Executive Officer of Enron Corp. and such officer has determined that such interest or participation does not adversely affect the best interests of the Company."

Powers Report, supra note 6, at 44 n.8.

190. Neither Fastow nor other participating Enron employees obtained Board permission for the conflict in the Chewco transaction, for example. Id. at 41.

191. For example, Fastow obtained appropriate permission for his participation as general partner in the LJM SPEs, based on the understanding that transactions between Enron and those SPEs be subject to approval by Enron's Chief Accounting Officer and Chief Risk Officer, and also be annually reviewed by Enron's Audit and Compliance Committee. Id. at 68-69, 71, 154. These controls, however, if implemented, "did not accomplish their intended purpose." Id. at 150.

192. Id. at 156.

193. Id. at 171.

194. I focus only on material, as opposed to all, such conflicts of interest because immaterial conflicts should not impair the judgment of the originator's management in setting up structured transac- 
more feasible. ${ }^{195}$ Once a conflict is identified, such a rule would not entail ongoing or active monitoring. This rule also should be effective because it reduces the agency-cost problem: absent conflicts, investors should be able to rely on the business judgment of the originator's management in setting up structured transactions for the originator's benefit.

Moreover, the postulated rule would not appear to impose any significant costs. Although it may be difficult to determine the existence of the conflict, ${ }^{196}$ that determination imposes no additional cost because conflicts already have to be identified in order to address the existing dutyof-loyalty requirements of corporate law. ${ }^{197}$ While there may be a cost to management of having to identify disclosure-impaired transactions, ${ }^{198}$ that identification would only have to be made in those limited cases where there is a material conflict. Absent such a conflict, identification is unnecessary. And, though it appears difficult to specify in advance any given set of criteria for defining what constitutes a disclosure-impaired transaction, ${ }^{199}$ disclosure impairment should be able to be assessed on an

tions for the originator's benefit. Even the Powers Report recognizes that it was the magnitude of the conflict that was most problematic in the Enron SPE transactions. Id. at 148.

195. The postulated rule is thus different from existing corporate law duty-of-loyalty requirements, which allow nonconflicted directors to approve conflicted transactions. See supra note 181 and accompanying text (discussing existing approaches to corporate law duty-of-loyalty requirements). My article proposes applying the postulated rule in place of such existing requirements in the relatively narrow context of insider disclosure-impaired transactions. The existing duty-of-loyalty requirements would continue to apply outside that context. Hence, a originator could enter into a conflicted transaction that is not disclosure impaired, so long as the transaction is approved by the originator's nonconflicted directors. I later explicitly compare the postulated rule with the existing duty-of-loyalty requirements, arguing that the former is more appropriate for insider disclosureimpaired transactions because, in that context, nonconflicted directors may not understand the conflicted transactions well enough to objectively assess them. See infra notes 209-14 and accompanying text (comparing the postulated rule with existing corporate law duty-of-loyalty requirements). I do not challenge, and indeed I am agnostic on, existing corporate law duty-of-loyalty requirements outside of that context.

196. Franklin A. Gevurtz, CORPORATION LAw 61 (2000) ("[W]hat constitutes a conflict-ofinterest is often not clear.").

197. See id.; see also 1 James D. Cox, Thomas Lee Hazen \& F. Hodge O'Neal, CorporaTIONS $\S 10.42$ (Supp. 2 1998) ("In most jurisdictions, interested directors are not counted toward the quorum necessary for the board to take action on the transaction in which the directors have a interest.") (citations omitted).

198. This identification would certainly be much easier than having to identify disclosureimpaired transactions, in which transaction costs and other externalities outweigh any public good, which would require an indeterminate balancing. See supra note 139 and accompanying text.

199. One such possible approach might be to define disclosure-impaired transactions as transactions for which contingent liabilities cannot be readily displayed. But that would appear to be too broad a definition because the material impact of structured transactions can rarely be quantified. See supra note 95 and accompanying text. Another approach might be to assume that all structured transactions are disclosure impaired, and thus effectively prohibit all conflicts of interest in these transactions. The simplicity of this solution is appealing, and it is not unprecedented-in the 1880 s, such a rule was generally enforced in the United States. See William L. Cary \& Melvin A. EisEnBERG, CORPORATIONS 647 (7th ed. 1995). But this approach again would be overly broad and, worse, it would merely shift the focus to trying to define what constitutes a "structured" transaction, creating the potential for regulatory arbitrage. See supra notes 137-39 and accompanying text. 
ad hoc basis, perhaps under the tenet "we know it when we see it."200 This notion reflects that disclosure impairment is easier to recognize than to define. ${ }^{201}$

Ad hoc assessment of disclosure impairment, however, introduces two possible costs. The first is that good conflicted transactions sometimes may be turned down. This cost should be small, however, because "there often appears to be no positive corporate or social purpose served by fair self-dealing transactions that could not be served by fair transactions with true outsiders." 202 For this reason, commentators have recently questioned whether corporate self-dealing should ever be permitted:

The often expressed justification for [favoring disclosure over prohibition is that the latter] prevents the corporation from entering advantageous contracts with its directors. It is an unexplored empirical question as to just how often corporations get deals from their directors which the company could not have received from someone else, and whether this prospect outweighs the advantages of having a simpler test. ${ }^{203}$

Indeed, Congress itself has recently indicated that prohibiting conflicts is appropriate in certain circumstances. ${ }^{204}$

The other possible cost is that an originator's management would be subject to the risk that a court, ex post, will second-guess the determina-

200. Justice Stewart once adopted a similar approach in defining obscenity. See Jacobellis v. Ohio, 378 U.S. 184, 197 (1964) (Stewart, J., concurring) ("I shall not today attempt further to define the kinds of material I understand to be embraced within [hard-core pornography]; and perhaps I could never succeed in intelligibly doing so. But $I$ know it when I see it, and the motion picture involved in this case is not that.") (emphasis added). Since then, the Supreme Court has adopted a more particular test for adjudicating obscenity cases. See Miller v. California, 413 U.S. 15, 24 (1973) ("[W]hether 'the average person, applying contemporary community standards' would find that the work, taken as a whole, appeals to the prurient interest....") (citations omitted); see also Roth v. United States, 354 U.S. 476, 489 (1957).

201. In pornography cases, courts err on the side of allowing First Amendment free speech. See Miller, 413 U.S. at 23 ("We acknowledge, however, the inherent dangers of undertaking to regulate any form of expression."). No constitutional issues are involved in making a disclosure impairment determination. Hence, courts need not decide such questions with a particular bias.

202. Robert C. Clark, Corporate Law 180 (1986). Professors Black and Kraakman suggest that the United States' shift from a prohibitive model in the late 1800 s-which imposed a strict prohibition on self-dealing - to the permissive model we now experience was not efficiency-or policy-based, but simply the result of lobbying by corporate managers. See Bernard Black \& Reinier Kraakman, $A$ Self-Enforcing Model of Corporate Law, 109 HARV. L. REV. 1911, 1975 (1996).

203. GEVURTZ, supra note 196, at 323 (emphasis added); accord CLARK, supra note 202, at 18089 (arguing that "all basic self-dealing presents a significant danger of abuse or unfairness, and the danger is not made insignificant by the safeguards in the prevailing legal rules or by other controls over managerial misconduct"). Even commentators willing to permit self-dealing under limited circumstances recognize that it is imperfect. See, e.g., 1 Cox, HAZEN \& O'NEAL, supra note 197, \& 10.42 n.3 (noting that although conflicted directors do not vote, as a practical matter they can still influence the votes of their fellow directors).

204. See, e.g., Sarbanes-Oxley Act of 2002, Pub. L. No. 107-204, § 402, 116 Stat. 745, 787-88 (codified at 15 U.S.C.A. $\$ 78 \mathrm{~m}(\mathrm{k})$ (West Supp. 2002)) (amending section 13 of the Securities Exchange Act of 1934 to prohibit issuers of securities from directly or indirectly making personal loans to directors and executive officers). The postulated rule is similar, if not more discrete, only prohibiting corporate managers from material conflicts of interest in disclosure-impaired transactions. 
tion of disclosure impairment. This risk likewise should be small. Where management determines a conflicted transaction is disclosure impaired, the originator simply will not engage in the transaction without eliminating the conflict. ${ }^{205}$ If management is wrong, then there should be no basis for a claim because, as discussed, companies appear to derive little, if any, benefit from fair self-dealing transactions that cannot be served by truly independent transactions. ${ }^{206}$ Management only would be exposed to risk when the originator enters into a conflicted transaction that management incorrectly determines not to be disclosure impaired. As in all other business decisions, however, management would then be protected by the business judgment rule: if members of management act in good faith and have a reasonable basis for their determination, then they cannot be penalized by an ex post contrary determination. ${ }^{207}$ This protection, ${ }^{208}$ and management's ability to err on the side of determining that transactions are disclosure impaired, should mitigate the second-guessing risk.

The postulated rule, therefore, should not impose any significant costs. But even if it did, such costs would be justified, because leaving only existing corporate law duty-of-loyalty requirements ${ }^{209}$ to govern conflicts in disclosure-impaired transactions would be even more costly. ${ }^{210}$

205. To eliminate the conflict, the originator sometimes may need to remove conflicted parties from both sides of the transaction - from the originator's side, and also from the side of the transaction itself - if necessary in order to remove any motivation such parties may have for using the transaction to take advantage of the originator.

206. See supra notes $202-03$ and accompanying text. Thus, at least one of the inefficiencies of ex post review being an imperfect filter - that some conflicted nondisclosure impaired transactions will be incorrectly treated as conflicted disclosure impaired transactions and not entered into-should not be costly.

207. See supra note 181 and accompanying text (discussing the business judgment rule). One might ask, however, why management's determination should be judged by the corporate law business-judgment-rule standard and not by a stricter securities-law-violation standard. I believe the former standard is more appropriate because the postulated rule-requiring management to be free of any material conflicts of interest stemming from disclosure-impaired transactions-is more akin to corporate law and corporate governance than to securities law. The most fundamental justification for the postulated rule is to protect shareholders where the originator contemplates entering into conflicted transactions that cannot be adequately disclosed to such shareholders, not ensuring that the ultimate disclosure is adequate. Indeed, the postulated rule does not need to address how a transaction is actually disclosed, and whether that disclosure satisfies securities laws.

208. Although this protection suffers the other inefficiency of ex post review being an imperfect filter-that some conflicted disclosure-impaired transactions will not be recognized-that is a price that must be paid in order to create a pragmatic system for management decision-making.

209. Those requirements allow nonconflicted board members to approve disclosure-impaired transactions as fair to the originator's investors. See supra note 181 and accompanying text; see also GEVURTZ, supra note 196, at 324 (observing that most states have adopted legislation providing that a conflicted corporate transaction will not be voidable where it is approved by disinterested directors or by shareholders, or where the transaction is proved to be fair; I do not focus on shareholder approval because there is little chance that shareholders will be able to understand the complexity where disinterested directors are unable to do so).

210. See GevURTZ, supra note 196, at 323 (noting that, in comparison with existing duty-ofloyalty requirements, a rule prohibiting conflicted transactions would have the "merit of simplicity"). Professor Gevurtz also maintains that a rule requiring a "fairness test means costly trials with uncertain outcomes. The indeterminacy of the fairness approach also means that occasionally directors may 
The existing requirements are ineffectual in those transactions, fostering waste and sheltering fraud, because board members, like investors, rarely are able to understand the complexities. In Enron, for example, few of senior management, including board members, understood its SPE deals. ${ }^{211}$ Testimony in derivatives cases likewise indicates that few board members understand those transactions. ${ }^{212}$ This should not be surprising: structured transactions are highly specialized and technical, and involve complex vocabularies. ${ }^{213}$ Directors seldom have the expertise to understand them, and they are not paid nearly enough to justify learning to do so. Even if, as some have recently suggested, corporate boards were to employ full-time professional directors, these directors are unlikely to be structured-transaction specialists, much less specialists in all forms of structured transactions. ${ }^{214}$

Furthermore, approval of conflicted disclosure-impaired transactions by disinterested directors could backfire, lulling investors into a false sense of security. Merely disclosing the existence of the conflicts is also inadequate. For example, the Enron conflicts were disclosed, ${ }^{215}$ yet investors did not adequately judge the risks. ${ }^{216}$

I therefore propose that government regulation should require management to be free of any material conflicts of interest in disclosureimpaired transactions. ${ }^{217}$ Of course, eliminating these conflicted transactions does not assure that structured transactions will ultimately benefit the originator's investors. Eliminating conflicts reduces, but does not eliminate, the risk that a company's management will enter into dubious transactions. Investors take this risk in any investment, however, and so long as corporate managers are permitted to exercise discretion, no amount of regulation can protect against it. ${ }^{218}$ But eliminating conflicts does increase the likelihood that the originator's management will at-

be able to get away with taking advantage of their corporations ...." Id. Complexity would increase both the cost and the indeterminacy of such a rule.

211. See supra note 35 and accompanying text.

212. See supra note 49 and accompanying text (citing management failures to understand derivatives, which lead to spectacular losses).

213. See supra notes $48-49$ and accompanying text.

214. Recall that structured transactions include derivatives transactions, securitization transactions, and other forms of structured financing.

215. See FRANK PARTNOY, INFECTIOUS GREED 331 (2003) (observing that "[a]nyone who closely read Enron's public filings from 2000 and 2001 would have spotted the description of Fastow's involvement and compensation").

216. This is not, of course, a complete answer because Enron is only a single case, and I have not provided empirical data of how investors respond to this disclosure in other cases. Nonetheless, it logically follows that if investors are unable to comprehend a transaction because of its complexity, see supra Part II.A, then they are also unlikely to understand the significance of conflicts in the transaction.

217. This article does not focus on remedies for breaching this regulation, other than to observe that such remedies should deter management malfeasance without deterring capable individuals from acting as managers.

218. This risk - that through bad judgment or just bad luck, management will guess wrong and make losing investments - is different from the risk that conflicted management will cause the originator to enter into questionable transactions. 
tempt to structure its transactions solely for the intended benefit of such investors. ${ }^{219}$

Whatever approach is taken to solving our Lemons problem, ${ }^{220}$ it should be cautioned that solutions will be imperfect because investors are sometimes irrational. ${ }^{221}$ Professor Gordon observes, for example, that

it was known and widely discussed in the analytic community that Enron's financial structure was highly complex and that the bodies were buried in off-balance sheet entities that were cryptically described in Enron's disclosure documents. No one on the outside really understood Enron's financial condition but they also knew they didn't know .... [I]n an efficient market, Enron should have been a 'lemons' stock instead of a 'faith' stock. ${ }^{222}$

\section{CONCLUSION}

The complexity of structured transactions undermines the long-held disclosure paradigm, in which sophisticated investors and securities analysts bring market prices into line with disclosure. Even if these parties were to consider hiring teams of experts as needed to decipher complex structured transactions, empirical evidence and theory both suggest that the information asymmetry between companies and their investors will remain. ${ }^{223}$

Proscribing structured transactions would forfeit their efficiency and other benefits. ${ }^{224}$ Tolerating insufficient disclosure likewise has a cost: the losses caused by the aforesaid information asymmetry. Continued reliance on disclosure as the sole means to remedy the information asymmetry is justified, therefore, only in the absence of cost-effective supplemental protections.

Although these protections might include governmental or privatesector certifications of quality, or even direct or indirect guaranties of value, this article argues that only one supplemental protection is

219. Management, of course, has an obligation to engage in transactions for the benefit of shareholders and, in certain cases, bondholders. Schwarcz, Rethinking a Corporation's Obligations to Creditors, supra note 132, at 647.

220. Akerlof, supra note 1, at 499.

221. See Gordon, supra note 83 , at 1236.

222. Id. at 1236 (referring to Akerlof, supra note 1); accord Healy \& Palepu, supra note 86, at 23 (noting that most investors continued to hold Enron stock even after articles about Enron's relatedparty transactions questioned the stock price); Sheila McNulty, A Victim of its Opacity, Fin. TIMES (London), Nov. 12, 2001, at 13 (observing that "[a]nalysts, who were paid to scrutinize [Enron], joked with journalists about failing to understand its books - and proceeded to issue the next 'buy' recommendation").

223. See supra notes 83-94 and accompanying text (arguing, among other things, that the cost of hiring experts can exceed, or at least appear to exceed, the benefit gained from fully understanding complex structured transactions; and that market imperfections, behavioral psychology, and practical limitations further undermine this balance).

224. See supra notes 124-31 (describing such efficiency and benefits). 
needed: a rule requiring management to be free of material conflicts of interest stemming from disclosure-impaired transactions. ${ }^{225}$ The rationale for this rule is that, in the face of complexity, investors must rely not only on disclosure, but also on the business judgment of management in setting up complex transactions for the company's benefit. To that end, the law similarly should focus on, in addition to disclosure, requiring management to be free of conflicts of interest that would affect management's judgment in those transactions. This focus would have prevented the conflicts of interest that allowed, and indeed encouraged, the Enron abuses to thrive.

I do not argue that the protection provided by this rule, coupled with disclosure and traditional constraints, such as gate keeping, will assure the legitimacy of the securities market. ${ }^{226}$ I only contend that because Enron and other recent scandals have created perceptions of distrust of the securities markets generally, and uneasiness with structured transactions specifically, it is important to inquire how to design costeffective controls to reduce these perceptions and their underlying reality, even though the controls may be second-best. ${ }^{227}$

In this context, a commentator at a workshop in which this article was presented likened this rule to sticking one's finger in the snow to try to stop a sled going downhill. ${ }^{228}$ That analogy, though intended to describe the limitations of the rule, is nonetheless useful in illustrating its strengths. Consider the movement of the sled to be financial innovation. Sledding is generally good, but if a sled glides too fast it can go out of control. Sticking one's finger in the snow may well be the appropriate remedy needed to slow down the sled in order to regain control. Similarly, financial innovation is generally good, and society should not want to discourage it. But it too can skid out of control, as was the case in Enron. By slowing down the propensity of managers to engage in conflicted structured transactions, the rule helps to ensure that financial innovation does not go out of control.

225. This rule certifies not quality per se, but a lesser, observable standard that may help to determine quality: the absence of conflicts of interest. That absence reduces the risk that an originator's management will structure transactions contrary to the interests of investors. See supra notes 194-99.

226. An additional limitation is that the rule itself will only be as good as its enforcement mechanism. Although this article does not discuss remedies, the rule expresses a corporate law duty, and thus the remedy for its breach should not depart greatly from remedies traditionally available for violations of corporate law.

227. It may well be that there is no "best" solution to the problem of complexity. Complexity is not simply a characteristic of the information per se but, more precisely, of the relationship between that information and the inherent limitations of the audience to which it is addressed. Cf. ISAIAH Berlin, The Crooked Timber of Humanity (Henry Hardy ed., 1991) (discussing humankind's limitations).

228. Comment of Richard A. Epstein, James Parker Hall Distinguished Service Professor, The University of Chicago (Oct. 22, 2002, John M. Olin Program in Law and Economics Workshop, The University of Chicago). 
